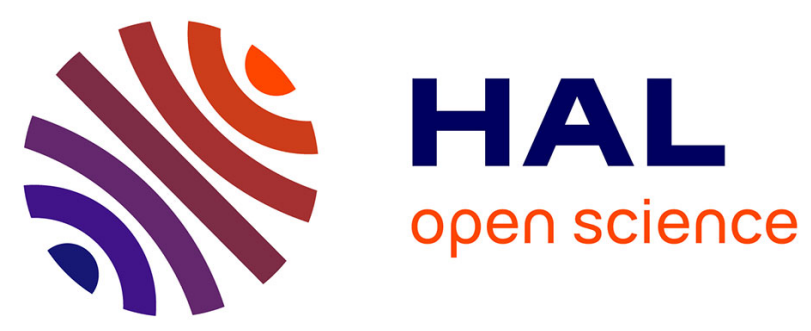

\title{
Magnetic Properties of Ferritchromite and Cr-Magnetite and Monitoring of Cr-Spinels Alteration in Ultramafic and Mafic Rocks
}

Florent Hodel, Mélina Macouin, Ricardo Ivan Ferrreira Trindade, Jefferson

F.D.F. Araujo, Marc Respaud, Jean-François Meunier, Laurent Cassayre,

Sonia Rousse, Loïc Drigo, Juliano Schorne-Pinto

\section{To cite this version:}

Florent Hodel, Mélina Macouin, Ricardo Ivan Ferrreira Trindade, Jefferson F.D.F. Araujo, Marc Respaud, et al.. Magnetic Properties of Ferritchromite and Cr-Magnetite and Monitoring of CrSpinels Alteration in Ultramafic and Mafic Rocks. Geochemistry, Geophysics, Geosystems, 2020, 21 (11), pp.0. 10.1029/2020GC009227 . hal-03116531

\section{HAL Id: hal-03116531 \\ https://hal.science/hal-03116531}

Submitted on 20 Jan 2021

HAL is a multi-disciplinary open access archive for the deposit and dissemination of scientific research documents, whether they are published or not. The documents may come from teaching and research institutions in France or abroad, or from public or private research centers.
L'archive ouverte pluridisciplinaire $\mathbf{H A L}$, est destinée au dépôt et à la diffusion de documents scientifiques de niveau recherche, publiés ou non, émanant des établissements d'enseignement et de recherche français ou étrangers, des laboratoires publics ou privés. 


\section{OATAO \\ Open Archive Toulouse Archive Ouverte}

\section{Open Archive Toulouse Archive Ouverte (OATAO)}

OATAO is an open access repository that collects the work of Toulouse researchers and makes it freely available over the web where possible

This is an author's version published in: http://oatao.univ-toulouse.fr/27258

Official URL: https://doi.org/10.1029/2020GC009227

\section{To cite this version:}

Hodel, Florent and Macouin, Mélina and Trindade, Ricardo Ivan Ferrreira and Araujo, Jefferson F.D.F. and Respaud, Marc and Meunier, Jean-François and Cassayre, Laurent $כ$ and Rousse, Sonia and Drigo, Loïc and Schorne Pinto, Juliano $\leftrightarrows$ Magnetic Properties of Ferritchromite and Cr-Magnetite and Monitoring of Cr-Spinels Alteration in Ultramafic and Mafic Rocks. (2020) Geochemistry, Geophysics, Geosystems, 21 (11).

Any correspondence concerning this service should be sent to the repository administrator: tech-oatao@listes-diff.inp-toulouse.fr 


\section{Geochemistry, Geophysics, Geosystems}

\author{
RESEARCH ARTICLE \\ 10.1029/2020GC009227 \\ Key Points: \\ - Main spinel alteration products \\ can be easily identified via \\ thermomagnetic measurements \\ - We redefine $\mathrm{Cr}$-magnetite as a $\mathrm{Fe}-\mathrm{Cr}$ \\ spinel $\left[\mathrm{FF}^{2+}\left(\mathrm{Fe}_{1-n} \mathrm{Cr}_{n}\right)_{2} \mathrm{O}_{4}\right]$, with 0.1 \\ $<n<0.2\left(6-13 \mathrm{wt} . \%\right.$ of $\left.\mathrm{Cr}_{2} \mathrm{O}_{3}\right)$ and \\ with a $T_{\mathrm{c}}$ at ca. $500-530^{\circ} \mathrm{C}$ \\ - This study opens the door to \\ magnetic monitoring of the $\mathrm{Cr}$ - \\ spinel alteration state in mafic and \\ ultramafic rocks
}

Supporting Information:

- Data Set S1

- Data Set S2

- Data Set S3

- Data Set S4

Correspondence to:

F. Hodel,

florent.hodel.geo@gmail.com

\section{Citation:}

Hodel, F., Macouin, M., Trindade, R. I. F., Araujo, J. F. D. F., Respaud, M., Meunier, J. F., et al. (2020). Magnetic properties of ferritchromite and cr-magnetite and monitoring of crspinels alteration in ultramafic and mafic rocks. Geochemistry, Geophysics, Geosystems, 21, e2020GC009227. https://doi.org/10.1029/2020GC009227

\section{Magnetic Properties of Ferritchromite and Cr-Magnetite and Monitoring of $\mathrm{Cr}$-Spinels Alteration in Ultramafic and Mafic Rocks}

\author{
F. Hodel ${ }^{1,2}$ (1) M. Macouin ${ }^{1}$, R. I. F. Trindade ${ }^{3}$ (D) J. F. D. F. Araujo ${ }^{4}$, M. Respaud ${ }^{5}$, J. F. Meunier ${ }^{6}$, \\ L. Cassayre $^{7}$ (D) S. Rousse ${ }^{1}$, L. Drigo ${ }^{1}$, and J. Schorne-Pinto ${ }^{7,8} \mathbb{D}$ \\ ${ }^{1}$ Géosciences Environnement Toulouse, OMP, Université Toulouse III Paul Sabatier, CNRS, IRD, UPS, Toulouse, France, \\ ${ }^{2}$ Laboratoire Chrono-Environnement, UMR6249 CNRS-UFC, Besançon, France, ${ }^{3}$ Instituto de Astronomia, Geofísica \\ e Ciências Atmosféricas, Universidade de São Paulo, São Paulo, Brazil, ${ }^{4}$ Department of Physics, Pontifical Catholic \\ University of Rio de Janeiro, Rio de Janeiro, Brazil, ${ }^{5} \mathrm{CNRS}$, CEMES, UPR 8011, Univ Toulouse, Toulouse, France, ${ }^{6} \mathrm{LCC}-$ \\ CNRS, Université de Toulouse, CNRS, Toulouse, France, ${ }^{7}$ Laboratoire de Génie Chimique, Université de Toulouse, \\ CNRS, INPT, UPS, Toulouse, France, ${ }^{8}$ General Atomics Center for Nuclear Technologies, University of South Carolina, \\ Columbia, SC, USA
}

\begin{abstract}
Spinel is a ubiquitous mineral in mafic/ultramafic rocks. Spinel cores chemistry is extensively used as a petrogenetic proxy while their alteration phases, ferritchromite, and Cr-magnetite, are used as metamorphic grade indicators. However, the magnetic properties and composition of these phases are still ill-defined and no consensus exists concerning the metamorphic conditions involved in their formation. Here, we use the magnetic properties of these Cr-spinel alteration phases, via fielddependent parameters and observations with a magnetic microscope coupled with mineral chemistry and Mössbauer spectroscopy, to better constrain their composition. We identify Cr-magnetite by a Curie point of ca. $520^{\circ} \mathrm{C}$. We show that it is characterized by an $n$ between 0.1 and 0.2 in the Fe-Cr spinel formula $\left[\mathrm{Fe}^{2+}\left(\mathrm{Fe}_{1-n} \mathrm{Cr}_{n}\right)_{2} \mathrm{O}_{4}\right]$, which corresponds to 6-13 wt.\% of $\mathrm{Cr}_{2} \mathrm{O}_{3}$. The abundance of Cr-magnetite indicates a strong alteration of $\mathrm{Cr}$-spinels that could reflect a significant hydrothermal activity rather than a high metamorphism grade. Normalized variation curves of the magnetic susceptibility during heating allow a relative quantification of the contributions of different magnetic phases to the magnetic susceptibility. This highlights a link between ferritchromite destabilization into maghemite at ca. $130^{\circ} \mathrm{C}$ followed by the destabilization of this maghemite starting at $300^{\circ} \mathrm{C}$. We identify specific covariation trends between these two magnetic species characterizing different alteration processes. This study opens the door to magnetic monitoring of the Cr-spinel alteration state in mafic and ultramafic rocks. It constitutes a new, fast, and weakly destructive way to study the petrological history of both terrestrial and extraterrestrial rocks.
\end{abstract}

Plain Language Summary Spinels are a common accessory mineral in Earth's mantle rocks, basaltic lavas and more generally, in mafic/ultramafic rocks from other telluric bodies. Because they are often (partially) preserved even in the case of highly altered rocks like serpentinites, and their chemistry is dependent on magmatic and metamorphic processes, they have been used for decades to investigate the history of their host rock. In this study, we focus on the magnetic and chemical characterization of the phases that compose spinel alteration rims, namely the ferritchromite and the Cr-magnetite (Chromiumrich magnetite). Coupling the magnetism and mineral chemistry methods allowed us to better constrain the magnetic behavior of these mineral phases, hence defining clear magnetic signatures for them and precise their chemical composition fields. We show that magnetic measurements can be used to finely monitor the spinels alteration state by quantifying the relative contributions of their different alteration products to the magnetization of a given rock sample. This constitutes a new way to study the metamorphic and/or hydrothermal history of both terrestrial and extraterrestrial rocks.

\section{Introduction}

Rock magnetism methods can be judiciously used to recognize and understand some metamorphic processes. Serpentinization reactions, for example, generate a significant amount of magnetite that magnetic methods allow to efficiently identify and quantify (O'Hanley, 1996, p. 277). However, other magnetic phases 
are less well constrained such as those of the $\mathrm{Cr}$-Fe-spinel series resulting from spinel alteration, which are important phases in igneous petrology studies.

Spinels are an abundant accessory mineral in mafic and ultramafic rocks of both terrestrial and extraterrestrial origin, from which they constitute the main aluminum phase (e.g., Barnes, 2000; Gattacceca et al., 2011). Cr-spinels in turn, besides being the main ore mineral for chromium, have been extensively used to constrain both the magmatic and metamorphic history of ultramafic rocks (e.g., Barnes, 2000; Barnes \& Roeder, 2001; Dick \& Bullen, 1984). Indeed, the chemistry of spinel core reflects partial melting and refertilization processes while spinel alteration rims (when present) testify the metamorphic conditions endured by their host rock (e.g., Barnes, 2000; Barnes \& Roeder, 2001; Dick \& Bullen, 1984). Spinels are commonly the only pristine mineral preserved in fully serpentinized peridotites, making them one of the most investigated minerals in these rocks (e.g., Ahmed \& Surour, 2016; Arai, 1994; Barnes, 2000; Barra et al., 2014; Dick \& Bullen, 1984; González-Jiménez et al., 2009; Hodel et al., 2017, 2019, 2020; Ishii et al., 1992; Marques et al., 2007; Mellini et al., 2005; Pearce et al., 2000; Saumur \& Hattori, 2013).

In ultramafic rocks, the typical metamorphic alteration pattern of spinels consists in variously developed Al-depleted rims, relatively enriched in $\mathrm{Fe}$ and $\mathrm{Cr}$, belonging to the Cr-Fe-spinel system (e.g., ferritchromite, Ahmed \& Surour, 2016; Barnes, 2000; González-Jiménez et al., 2009; Hodel et al., 2017; Mellini et al., 2005; Saumur \& Hattori, 2013). In extreme stages, iron oxide rims depleted in $\mathrm{Al}, \mathrm{Mg}$, and $\mathrm{Cr}$ are produced, corresponding to Cr-rich magnetite and magnetite (e.g., Hodel et al., 2017). These exsolved elements participate in the formation of clinochlore, which precipitates in the form of blades surrounding spinel grains (e.g., Hodel et al., 2017, 2018). Large Fe-rich alteration rims are generally interpreted as an evidence of high metamorphic grades, making spinel alteration patterns a widely used metamorphic indicator (e.g., amphibolite facies with $T<550^{\circ} \mathrm{C}$, Ahmed \& Surour, 2016; Barnes, 2000; González-Jiménez et al., 2009; Mellini et al., 2005). However, some studies show that spinel chemistry can be strongly affected by mantle metasomatism (El Dien et al., 2019) or after emplacement at low temperatures and low metamorphic grades (e.g., Barra et al., 2014; Saumur \& Hattori, 2013), particularly in hydrothermal environments (e.g., Hodel et al., 2017; Marques et al., 2007). For instance, Marques et al. (2007) showed evidence of significant spinel zonation in serpentinites from the active Rainbow hydrothermal vent field. Hodel et al. $(2017,2018)$ identified similar patterns in serpentinites that constitute the relics of a Neoproterozoic (ca. $760 \mathrm{Ma}$ ) fossil black-smoker hydrothermal system. These studies suggest that major mineralogical changes in spinels can be strongly dependent on the nature of the metamorphic/alteration event. Hence, the use of the spinel alteration state as an indicator of the metamorphic grade should be carefully considered.

Minerals from the Cr-Fe spinel suite have specific magnetic properties depending on Fe-Cr ion substitutions during alteration processes from which they originate (e.g., Hodel et al., 2017; Horen et al., 2014; Kadziałko-Hofmokl et al., 2008; Ziemniak \& Castelli, 2003). Ziemniak and Castelli (2003) and references therein discussed the magnetism of the $\mathrm{Fe}_{3} \mathrm{O}_{4}-\mathrm{FeCr}_{2} \mathrm{O}_{4}$ system from a theoretical and experimental point of view. However, very few studies discussed the magnetic properties of $\mathrm{Cr}$-spinel alteration products, notably of the intermediate phases between Chromite and Magnetite endmembers (Horen et al., 2014; Hodel et al., 2017; Kądziałko-Hofmokl et al., 2008, 2010). In their mineralogical and paleomagnetic studies, Kądziałko-Hofmokl et al. (2008, 2010) detected "highly magnetic Cr-magnetite with Curie temperature $\left(T_{\mathrm{c}}\right)$ of $530^{\circ} \mathrm{C}$ " as well as "less magnetic phases with $T_{\mathrm{c}}$ ranging from about 100 to $450^{\circ} \mathrm{C}$ ". These results highlight the potential of magnetic methods in the study of these alteration products.

Our study aims to identify magnetic signatures of spinel alteration products, but also to explore whether these signatures can help to identify the processes from which they originate. We apply different approaches for the determination of magnetic mineralogy that we couple with Mössbauer spectrometry and mineral chemistry. We present and compare magnetic, Mössbauer and geochemical data from four Neoproterozoic ultramafic units from Brazil and Morocco representing different geological settings and different degrees of spinel alteration. This integrated approach allows us to associate particular magnetic signatures commonly observed in mafic and ultramafic rock in order to chemically constrain spinel alteration products. Our results testify that magnetic measurements efficiently identify poorly recognized $\mathrm{Cr} / \mathrm{Fe}$ minerals and assess their chemical variability. 

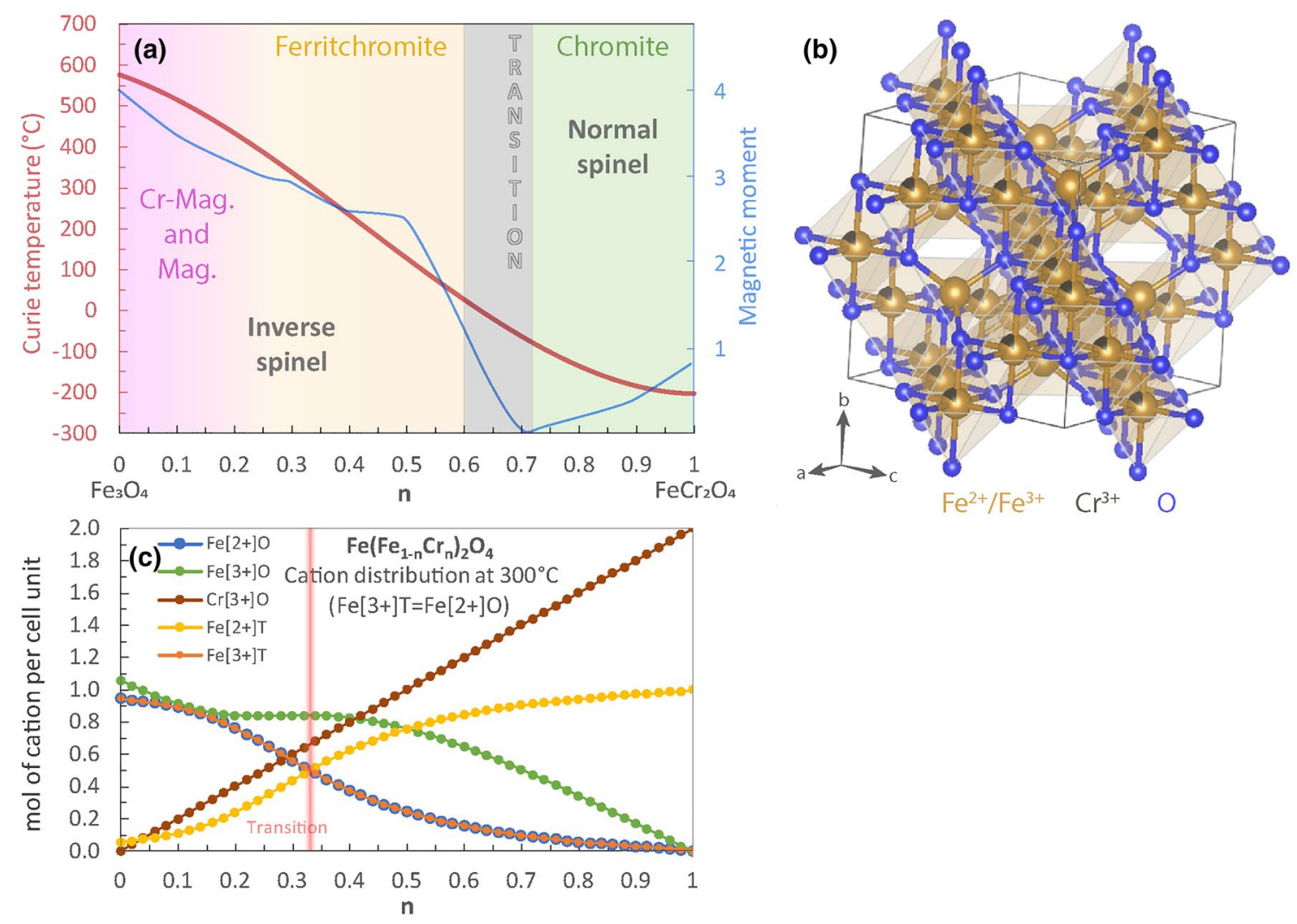

Figure 1. (a) Curie temperature and magnetic moment evolution of the spinel system $\left[\mathrm{Fe}^{2+}\left(\mathrm{Fe}_{1-n} \mathrm{Cr}_{n}\right)_{2} \mathrm{O}_{4}\right]$ showing the transition from normal spinel (i.e., chromite pole, $\mathrm{FeCr}_{2} \mathrm{O}_{4}, n=1$ ) to inverse spinel (Mag. = magnetite pole, $\mathrm{Fe}_{3} \mathrm{O}_{4}, n=0$ ). Ferritchromite and Cr-magnetite (Cr-Mag.) are inverse spinel intermediate phases between these two end-members. After Dunlop and Ozdemir (1997), Horen et al. (2014), Kadzialko-Hofmokl et al., (2008), Robbins et al. (1971), and Ziemniak and Castelli (2003). (b) Crystallographic structure of the spinel system for $n=0.15\left[\mathrm{Fe}^{2+}\left(\mathrm{Fe}_{0.85} \mathrm{Cr}_{0.15}\right)_{2} \mathrm{O}_{4}\right]$. (c) Cation distribution of the spinel system $\left[\mathrm{Fe}^{2+}\left(\mathrm{Fe}_{1-n} \mathrm{Cr}_{n}\right)_{2} \mathrm{O}_{4}\right]$ calculated with the FactSage software (see Data Set S1, Decterov et al., 2004; Bale et al., 2016).

\section{The Chromium-Iron Spinel System}

The Cr-Fe spinel system is expressed with the formula $\mathrm{Fe}^{2+}\left(\mathrm{Fe}_{1-n} \mathrm{Cr}_{n}\right)_{2} \mathrm{O}_{4}$, where $0<n<1$ represents the molar fraction of chromite (Figure 1). The two end-members of the system are pure chromite $\left(\mathrm{FeCr}_{2} \mathrm{O}_{4}\right)$ for $n=1$ and magnetite $\left(\mathrm{Fe}_{3} \mathrm{O}_{4}\right)$ for $n=0$ (e.g., Ziemniak \& Castelli, 2003).

The phases in the Fe-Cr-spinel system share an almost ideal cubic structure with an arrangement of oxygen atoms gathered either in tetrahedral or octahedral sites (Figure 1b). Tetrahedral sites generally host divalent cations like $\mathrm{Mg}^{2+}, \mathrm{Fe}^{2+}$ and accessory $\mathrm{Ni}^{2+}, \mathrm{Zn}^{2+}, \mathrm{Mn}^{2+}$, etc... while octahedral sites host trivalent cations such as $\mathrm{Fe}^{3+}, \mathrm{Cr}^{3+}$, or $\mathrm{Al}^{3+}$. Thermodynamic models of the Fe-Cr-O system (e.g., Decterov et al., 2004; Taylor \& Dinsdale, 1993) calculate the cation distribution in the spinel structure, depending on temperature and composition. The cation distribution calculated with the FactSage software and the FToxid database (Bale et al., 2016) at $300^{\circ} \mathrm{C}$ is provided in Figure 1c.

The chromite end-member $\left(\mathrm{FeCr}_{2} \mathrm{O}_{4}\right)$ presents a normal spinel structure where each type of cation is situated in their dedicated sites as described above. Chromite is ferromagnetic with a $T_{\mathrm{c}}$ of $-202.15^{\circ} \mathrm{C}$; therefore it does not carry a remanent magnetization at ambient temperature (Ziemniak \& Castelli, 2003, Figure 1a). Conversely, the pure magnetite end-member $\left(\mathrm{FeFe}_{2} \mathrm{O}_{4}\right)$ carries a strong remanent magnetization with a $T_{\mathrm{c}}$ of $580^{\circ} \mathrm{C}$ (Petersen \& Bleil, 1982) (Figure 1a). It displays an inverse spinel structure where the octahedral sites host only trivalent cations of $\mathrm{Fe}^{3+}$, which are also present in the tetrahedral sites together with divalent $\mathrm{Fe}^{2+}$ (Lenaz et al., 2004) (Figures $1 \mathrm{~b}$ and 1c).

Between the two end-members, the physical and structural properties of the Cr-Fe spinel system $\left[\mathrm{Fe}^{2+}\left(\mathrm{Fe}_{1-}\right.\right.$ $\left.{ }_{n} \mathrm{Cr}_{n}\right)_{2} \mathrm{O}_{4}$ ] depend on the different contributions of normal and inverse structures. Thus, properties such as 
the $T_{\mathrm{c}}$ or saturation magnetization vary as a function of $n$ (e.g., Robbins et al. 1971; Ziemniak \& Castelli, 2003). Both parameters decrease with the increase of Cr content for $n$ varying between 0 and ca. 0.7 corresponding to the inverse spinel structure (Figure 1). For $n$ between ca. 0.7 and 1, the normal spinel structure exhibits a continued decrease of the $T_{\mathrm{c}}$ while saturation magnetization slightly increases with $n$ (Figure 1a).

Ferritchromite and chromium magnetite (Cr-magnetite) terms are used to describe intermediate phases of the spinel system but the $n$ value corresponding to the transitions between these two minerals are not well constrained yet. At room temperature, Cr-Fe spinels become ferrimagnetic when the solid solution is characterized by $n \leq 0.6$. (Robbins et al., 1971; Ziemniak \& Castelli, 2003). This limit $(n=0.6)$ has therefore been applied to define the superior compositional boundary of ferritchromite in terms of Cr content (Figure 1a). Kądziałko-Hofmokl et al. (2008) defined the Cr-magnetite according to its magnetic properties, that is, a ferritchromite with a magnetic behavior close to that of magnetite in terms of saturation magnetization and $T_{\mathrm{c}}$. Yet, Cr-magnetite is still not defined in terms of its chemical composition, and a better constraint on this transition and the associated $n$ value is needed.

In natural $\mathrm{Fe}-\mathrm{Cr}$ spinels, other cations, such as $\mathrm{Al}, \mathrm{Mg}, \mathrm{Mn}, \mathrm{Ni}$, and $\mathrm{Ti}$, are also present in varying amounts and may influence the spinel physical properties. Indeed, incorporation of impurities in pure magnetite produces a widening and a shift toward lower temperatures of the magnetite Verwey transition (initially at 121 K) (e.g., Barlow et al., 1987; Brabers et al., 1998; Honig, 1995; Kakol, 1990; Özdemir et al., 1993). Nevertheless, experiments of Chhaya et al. (1999) in synthetic spinel systems demonstrated that minor amounts of $\mathrm{Al}$ or $\mathrm{Ni}$ in chromite $\left(\mathrm{FeCr}_{2} \mathrm{O}_{4}\right)$ do not significantly modify the relationship between $n$ and $T_{\mathrm{c}}$. Thus, the determination of $T_{\mathrm{c}}$ should be a powerful way to identify different $\mathrm{Cr}$-Fe spinel phases, providing a new way to monitor the spinel alteration state in mafic and ultramafic rocks.

\section{Geological Setting, Host Rocks, and Cr-Spinel Alteration State}

This study is based on extensive sampling of ultramafic units from Neoproterozoic ophiolites in Brazil (the Araguaia Belt, Hodel et al., 2019) and Morocco (Bou Azzer and Khzama, Hodel et al., 2017, 2018, 2020). All samples investigated are fully serpentinized peridotite (hydrated mantle) that have been differently affected by obduction-related metamorphism and, for some of them, by intense hydrothermal alteration (Hodel et al., 2017, 2018). Due to these different metamorphic/hydrothermal histories, Cr-spinels from these serpentinites exhibit various alteration patterns and intensities (Figure 2). Hence, they constitute prime targets to study Cr-spinel alteration processes as well as the resulting alteration products and their magnetic properties. The main serpentinites petrographic features from the four studied units are listed below.

\subsection{Serpentinites From Araguaia Belt Ultramafic Units}

Serpentinites from Araguaia Belt ultramafic units are located between the Amazonian Craton and the Paranaïba basin in central Brazil (see the detailed petrographic and petrological study in Hodel et al., 2019). They display a classical pseudomorphic mesh texture mainly constituted of lizardite/chrysotile assemblages (low-temperature serpentine varieties), attesting to a static oceanic-like serpentinization and a regional metamorphism that involved temperatures below $350^{\circ} \mathrm{C}$ (e.g., Evans, 2004; Hodel et al., 2019; Mével, 2003; Schwartz et al., 2013). Spinels of these serpentinites are generally well-preserved and weakly altered (Figures $2 \mathrm{a}$ and $2 \mathrm{~b}$ ).

\subsection{Serpentinites From the Khzama Ophiolite}

Serpentinites from the Khzama ophiolite are located in the Sirwa Inlier, in the Moroccan Anti-Atlas (see the detailed petrographic and petrological study in Hodel, 2017 and Hodel et al., 2020). These rocks are essentially antigorite and generally present a nonpseudomorphic texture characteristic of high-temperature serpentinization $\left(T>350^{\circ} \mathrm{C}\right.$, Evans, 2004; Schwartz et al., 2013). Lizardite/chrysotile assemblages, sometimes occurring in the form of nodules within the antigoritic matrix, seem to indicate a first episode of serpentinization at a lower temperature $\left(<350^{\circ} \mathrm{C}\right.$, Hodel, 2017), prior to antigoritization which likely occurred during the obduction of the ophiolitic sequences (Hodel, 2017; Hodel et al., 2020). Despite this important metamorphism episode involving temperatures above $350^{\circ} \mathrm{C}$, spinels of these serpentinites are only weakly altered (Figures 2c and 2d). 

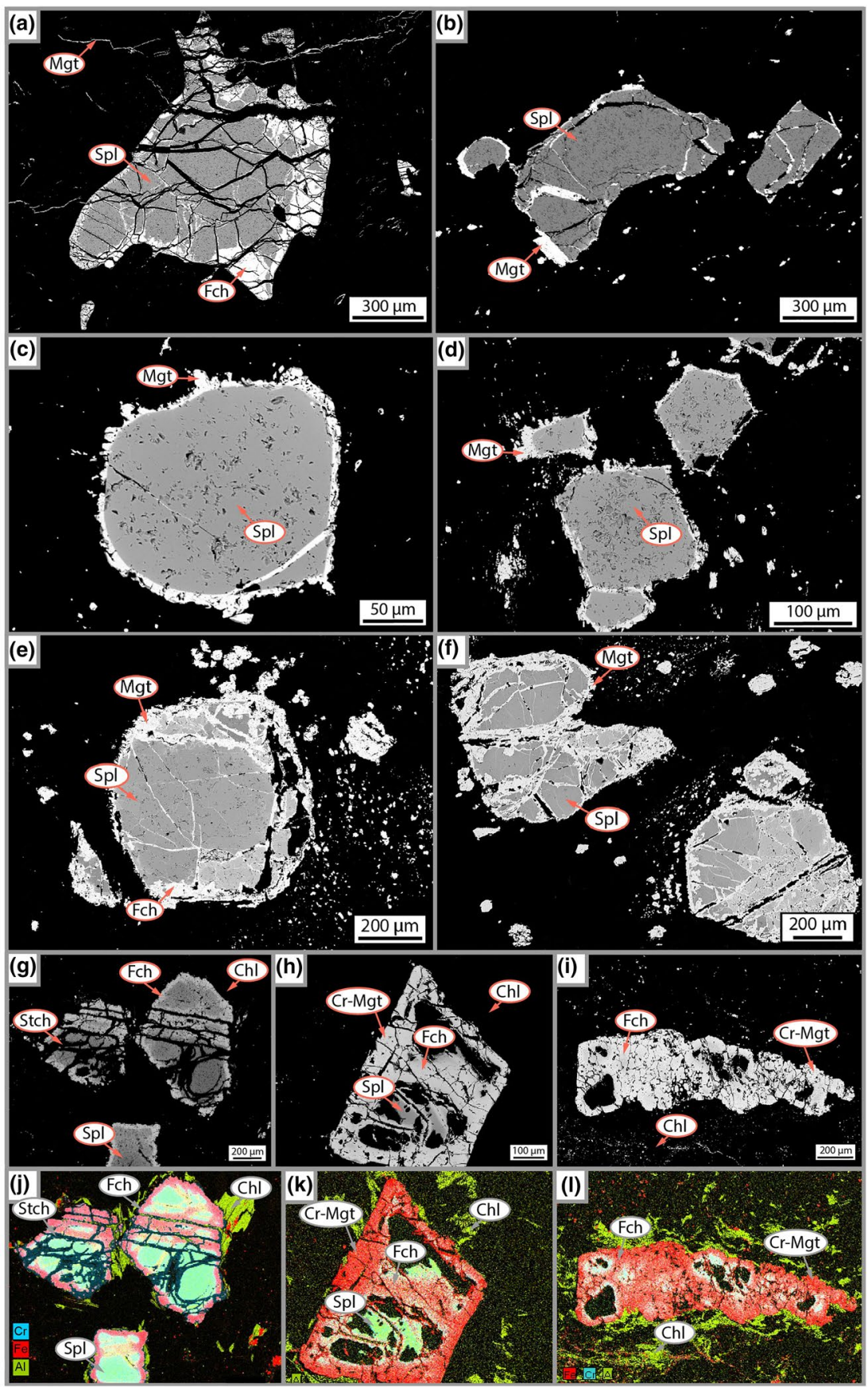

Figure 2. (a-f) Examples of backscattered electron microphotographs (using SEM) of very weakly altered spinels in serpentinites from the Araguaia Belt (a and b), Khzama (c and d) and South Aït Ahmane (e and f). (g-i) Examples of BSE microphotographs of variously altered spinels from the North Aït Ahmane unit. Alteration state increasing from left to right. It is worth to note that large oxide grains in BSE images (i.e., tens to hundreds $\mu \mathrm{m}$ large) are not serpentinization related pure magnetite, which are much smaller, but small $\mathrm{Cr}$-spinel grains or $\mathrm{Cr}$-spinel alteration rims fragments. ( $\mathrm{j}-\mathrm{l}) \mathrm{SEM}$ multi-elemental maps displaying $\mathrm{Cr}, \mathrm{Fe}$, and $\mathrm{Al}$ repartition in the same altered grains (g, $\mathrm{h}$, $\mathrm{i}$, respectively) and in the surrounding clinochlore blades (Al-rich phases, in green around spinels grains). $\mathrm{Cr}-\mathrm{Mgt}, \mathrm{Cr}-$ magnetite; Fch, ferritchromite; Mgt, magnetite; SEM, scanning electron microscope; Spl, preserved spinel cores; Stch, stichtite. (g-l) were modified after Hodel et al. (2017). 


\subsection{Serpentinites From the Southern Ultramafic Unit of the Aït Ahmane Ophiolitic Sequence}

Serpentinites from the southern ultramafic unit of the Aït Ahmane ophiolitic sequence (Bou Azzer ophiolite, Moroccan Anti-Atlas, see the detailed petrographic and petrological study in Hodel, 2017 and Hodel et al., 2020). These serpentinites are very similar to those of the Khzama ophiolite. They also present nodules made of lizardite/chrysotile assemblages within an antigoritic matrix. Thus, a two-step serpentinization scenario, similar to the one proposed for Khzama serpentinites, is likely for these serpentinites. As in the case of the Khzama serpentinites, the spinels of these serpentinites are also weakly altered (Figures 2e and 2f).

\subsection{Serpentinites of the Northern Ultramafic Unit of the Aït Ahmane Ophiolitic Sequence}

Serpentinites of the northern ultramafic unit of the Aït Ahmane ophiolitic sequence (Hodel, 2017; Hodel et al., 2017, 2018). They generally display pseudomorphic texture essentially made of lizardite/chrysotile assemblages attesting a static oceanic-like serpentinization and a weak obduction related metamorphism that involved temperatures below $350^{\circ} \mathrm{C}$ (e.g., Evans, 2004; Mével, 2003; Schwartz et al., 2013). Hodel et al. $(2017,2018)$ showed that these serpentinites are often strongly altered due to an intense black-smoker type hydrothermal activity which affected them before their obduction. The spinels of these serpentinites are highly altered, being strongly affected by this hydrothermal episode (Hodel et al., 2017) (Figures 2g-2l).

\section{Methods}

\subsection{Petrography and Mineral Chemistry}

Back-scattered electron (BSE) images and elemental mappings were performed using a JEOL JSM-6360LV Scanning Electron Microscope (SEM) at the Geoscience Environnement Toulouse laboratory (France) operating at $20 \mathrm{kV}$ with an Electron Dispersive System (EDS), which allows for in-situ qualitative characterization of the chemical composition. The quantitative chemical composition of spinels and their different alteration phases were determined using a Cameca SXFive electron microprobe at the Raimond Castaing Microcharacterization Center (University of Toulouse III, Paul Sabatier) in France and a JEOL JXA-8230 electron microprobe at the Microanalysis Laboratory of the Federal University of Ouro Preto in Brazil. On the Cameca SXFive, the measurements were done under a voltage of $15 \mathrm{kV}$ and a current of $20 \mathrm{nA}$. The size of the analysis spot was about $4 \mu \mathrm{m}$. The standards used were: albite ( $\mathrm{Na})$, corundum (Al), periclase $(\mathrm{Mg})$, sanidine $(\mathrm{K})$, wollastonite $(\mathrm{Ca}, \mathrm{Si})$, pyrophanite $(\mathrm{Mn}, \mathrm{Ti})$, hematite $(\mathrm{Fe})$, chromite $(\mathrm{Cr}), \mathrm{NiO}(\mathrm{Ni})$, sphalerite $(\mathrm{Zn})$, tugtupite $(\mathrm{Cl})$, barite $(\mathrm{Ba})$, and topaz $(\mathrm{F})$. The detection limits are $0.01 \mathrm{wt}$ \%. On the JEOL JXA-8230, the analytical conditions were a voltage of $15 \mathrm{kV}$ and a current of $20 \mathrm{nA}$. The size of the analysis spot was about $5 \mu \mathrm{m}$. The standards used were: anorthoclase $(\mathrm{Na})$, olivine $(\mathrm{Mg})$, corundum $(\mathrm{Al})$, microcline $(\mathrm{K})$, quartz $(\mathrm{Si})$, microcline $(\mathrm{K})$ and $\mathrm{Cu}$-augite $(\mathrm{Ca})$, ilmenite $(\mathrm{Mn}, \mathrm{Ti})$, almandine (Fe), chromite (Cr), Glass-Rhyolitic IR-X standard (Ni), gahnite $(\mathrm{Zn})$, scapolite $(\mathrm{Cl})$, barite $(\mathrm{Ba})$, and $\mathrm{CaF} 2(\mathrm{~F})$. The detection limits are 0.01 wt. \%. $\mathrm{Fe}_{2} \mathrm{O}_{3}$ concentrations were calculated according to stoichiometric compositions of the spinel system (Droop, 1987).

\subsection{Magnetic Measurements}

The magnetic susceptibility variations as a function of temperature were measured using an AGICO KLY-3 kappabridge coupled with an AGICO CS-3 heating unit at the Geosciences Environnement Toulouse (GET) laboratory in France and at the Laboratorio de Paleomagnetismo da Universidade de São Paulo (USPMag) in Brazil. Each measurement cycle consisted of continuous measurements of magnetic susceptibility over a heating/cooling cycle from room temperature to a peak temperature of $700^{\circ} \mathrm{C}$ with a heating/cooling rate of $14^{\circ} \mathrm{C}$ per minute, under an inert Argon atmosphere. In a previous study, Hodel et al. (2017) used the tangent method to determine $T_{\mathrm{c}} \mathrm{s}$. Given the important $\mathrm{Cr}$ content of the investigated magnetic phases, we here used the inverse susceptibility method in order to avoid any bias. These two methods are described in Petrovský and Kapička (2006). The data were then processed using AGICO Cureval 8.0.1 software. In order 
to quantify the relative contribution of each magnetic species to the magnetic susceptibility, we used the normalized gradient (or its absolute values) of the magnetic susceptibility curve in heating [i.e., the first derivative: $\left(K T_{t+1}-K T_{t}\right) /\left(T_{t+1}-T_{t}\right)$, where $K T$ is the magnetic susceptibility at a given temperature and $T$ the corresponding temperature] as described in Hodel et al. (2017).

Measurements of magnetic susceptibility at low temperatures were carried out at the Laboratoire de Chimie de Coordination (LCC) in Toulouse, France. They were acquired with an MPMS XL from Quantum design with frequencies of $1,000 \mathrm{~Hz}$ and $50 \mathrm{~Hz}$.

Hysteresis parameters determinations, 15 first-order reversals curves (FORC) and 56 acquisitions of isothermal remanent magnetization (IRM) were performed on vibrating sample magnetometers (VSM, Princeton Measurements Corporation) at the Institut de Physique du Globe de Paris (IPGP) in France and at the USPMag in Brazil. The determinations carried out for the Ait Ahmane samples are already reported in Hodel et al. (2017).

IRM curve acquisitions were performed with an increasing induced field (100 steps) up to $1 \mathrm{~T}$. The statistical analysis of the IRM acquisition curves, following the approach proposed by Kruiver et al., (2001), Egli (2003, 2004), and Heslop et al. (2004), were processed using the Maxunmix software of Maxbauer et al. (2016). This software has the advantage of being able to analyze magnetic mineral components with coercivities that are not log-normal, common in natural samples, by incorporating skewness (Egli, 2003; Heslop et al., 2004; Maxbauer et al., 2016). The magnetic components were chosen to obtain the best fit with the total IRM acquisition using the fewest possible numbers of components. For each sample, 100 FORCs (First order Reversal Curve) were measured with an average time on each point of $200 \mathrm{~ms}$ and a one-second pause between each measurement. FORC diagrams were generated using FORCinel v3.0 software (Harrison \& Feinberg, 2008) with a smoothing factor (Roberts et al., 2000) of 5 (for all samples) and paramagnetic correction.

\subsection{Mössbauer Spectroscopy}

Mössbauer spectroscopy analyses were performed at the LCC Laboratory in France. Spectra were collected on a constant-acceleration conventional spectrometer with a $0.30 \mathrm{GBq}$ source of ${ }^{57} \mathrm{Co}$ ( $\mathrm{Rh}$ matrix) at $80 \mathrm{~K}$, using a JANIS cryostat. The thermal scanning was monitored by a temperature controller LAKESHORE 335. The absorber was a sample of about $100 \mathrm{mg}$ of powder that was enclosed in a $20 \mathrm{~mm}$ diameter cylindrical plastic sample holder. Mössbauer's parameters were fitted to a Lorentzian model using the Recoil software. The isomer shift values are given with respect to metallic iron at room temperature. A table of parameters is provided in Data Set S2.

\subsection{Magnetic Scanning Microscopy}

The distribution of magnetization in the thin section was obtained using a custom-made magnetic scanning microscope in the Instrumentation and Magnetic Measurement Laboratory of the Physics Department of Pontificia Universidade Catolica do Rio de Janeiro (PUC-Rio) in Brazil. The equipment was developed by Pereira et al. (2017), and its potential use in rock thin sections was outlined by Araujo et al. (2019). The microscope operates with a pair of commercial Hall effect sensors. Both sensors were mounted with their sensitivity axes in opposite directions forming an axial gradiometer to measure the magnetic properties of minerals in thin sections ( $30 \mu \mathrm{m}$ thick). A magnetic field of $140 \mathrm{mT}$ was applied perpendicular to the surface of the sample. Maps were performed with steps of $250 \mu \mathrm{m}$ for low resolution maps and $50 \mu \mathrm{m}$ for higher resolution maps. The sensitivity to magnetic moment is $8.8 \times 10^{-11} \mathrm{Am}^{2}$. Punctual hysteresis curves were obtained after magnetic scanning microscopy mappings. Acquisition consists in applying a magnetic field $\mathrm{DC}(\mathrm{T})$ to the sample while the reading system measures the induced magnetic field $\mathrm{J}(\mathrm{mT})$ in the $z$ direction of the sample. Although these curves do not have a theoretical model necessary to obtain the exact magnetic moment of the rock, they nonetheless allow for a qualitative assessment of the local mineralogy. 


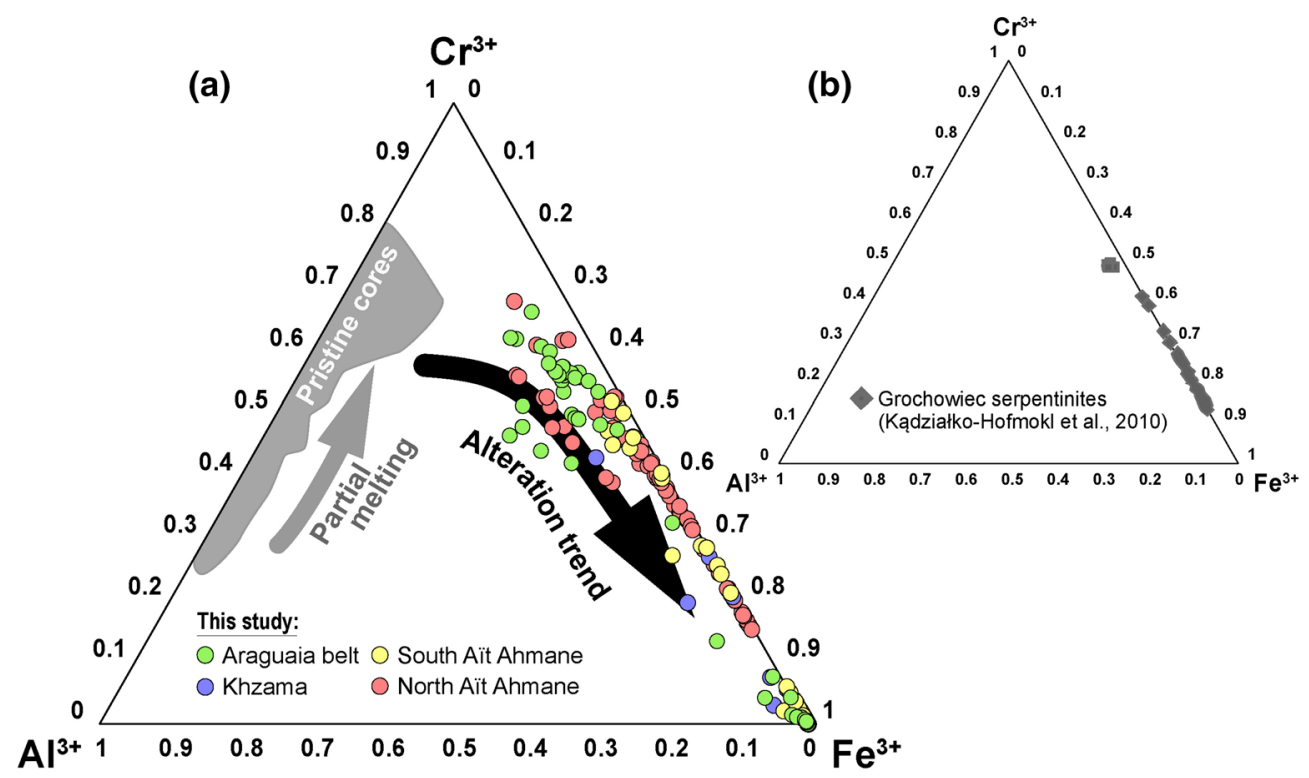

Figure 3. Ternary plot of trivalent cation concentrations $\left(\mathrm{Al}^{3+}, \mathrm{Cr}^{3+}\right.$, and $\left.\mathrm{Fe}^{3+}\right)$ in spinel alteration rims from (a) the four studied serpentinite units (data for North Aït Ahmane serpentinites are from Hodel et al., 2017; core compositions are from Hodel et al., 2017, 2019) and (b) from the Grochowiec serpentinites (Poland) in which Kądziałko-Hofmokl et al. (2010) detected a spinel alteration phase with a $T_{\mathrm{c}} \mathrm{ca} .530^{\circ} \mathrm{C}$.

\section{Results}

\subsection{Spinels Alteration State: Petrography and Mineral Chemistry}

Spinels of the different serpentinite units display various degrees of alteration, characterized by more or less wide alteration rims, with a wide range of chemical compositions. Major element compositions of spinel alteration rims in serpentinites from the four studied ophiolitic units are given in Data Set S3.

Spinels in the analyzed samples show contrasting behavior. Spinels from Araguaia Belt, Khzama, and South Aït Ahmane ultramafic units are generally weakly altered (Figures 2a-2f). They display large preserved cores, surrounded by thin, sometimes discontinuous rims composed of two types of $\mathrm{Cr}$-Fe-spinels. The first one presents $\mathrm{Cr}_{2} \mathrm{O}_{3}$ contents between 0 and $5 \mathrm{wt}$.\%, which correspond to $0<n<0.08$ in the Cr-Fe-spinel system formula $\left(\mathrm{Fe}^{2+}\left(\mathrm{Fe}_{1-n} \mathrm{Cr}_{n}\right)_{2} \mathrm{O}_{4}\right)$. The second one is richer in $\mathrm{Cr}_{2} \mathrm{O}_{3}$ that is rarely below 13 wt.\% of $\mathrm{Cr}_{2} \mathrm{O}_{3}(n$ $=0.21$ ) (Figure 3). Spinel alteration aureoles of Araguaia Belt serpentinites are generally thicker compared to the Khzama and Aït Ahmane ones. They, sometimes, obliterate the entirety of the primary spinel. Rims from the Araguaia Belt serpentinites are sometimes very rich in $\mathrm{SiO}_{2}$ (up to 18.50 wt.\%) and $\mathrm{MgO}$ (21.24 wt.\%), which probably reflects a mixture with serpentine or other magnesium-silicate phases due to the porous nature of the rims (e.g., Ahmed and Surour, 2016).

In contrast to the other studied units, the spinels of the North Aït Ahmane serpentinites are much more altered (Figures 2 and 3a) (Hodel et al., 2017, 2018). They often display large Cr-Fe-spinel rims, sometimes replacing the entirety of the initial spinel grains (Hodel et al., 2017) (Figures $2 \mathrm{i}$ and 21). These rims show a wide range of compositions (Figures 2 and 3a) but the $\mathrm{Cr}_{2} \mathrm{O}_{3}$ content of these alteration phases is never lower than 9.70 wt.\% $(n=0.15)$.

\subsection{Thermomagnetic Curves}

Thermomagnetic curves of serpentinites with both weakly altered (Araguaia, Khzama, and South Aït Ahmane) and strongly altered (North Aït Ahmane) spinels show several mineralogical transformations and Curie points (Figures 4 and 5).

Thermomagnetic curves display a sudden increase in magnetic susceptibility at around $130^{\circ} \mathrm{C}$ during the first heating. The magnetic susceptibility continues to increase until $300-350^{\circ} \mathrm{C}$ where it reaches a 

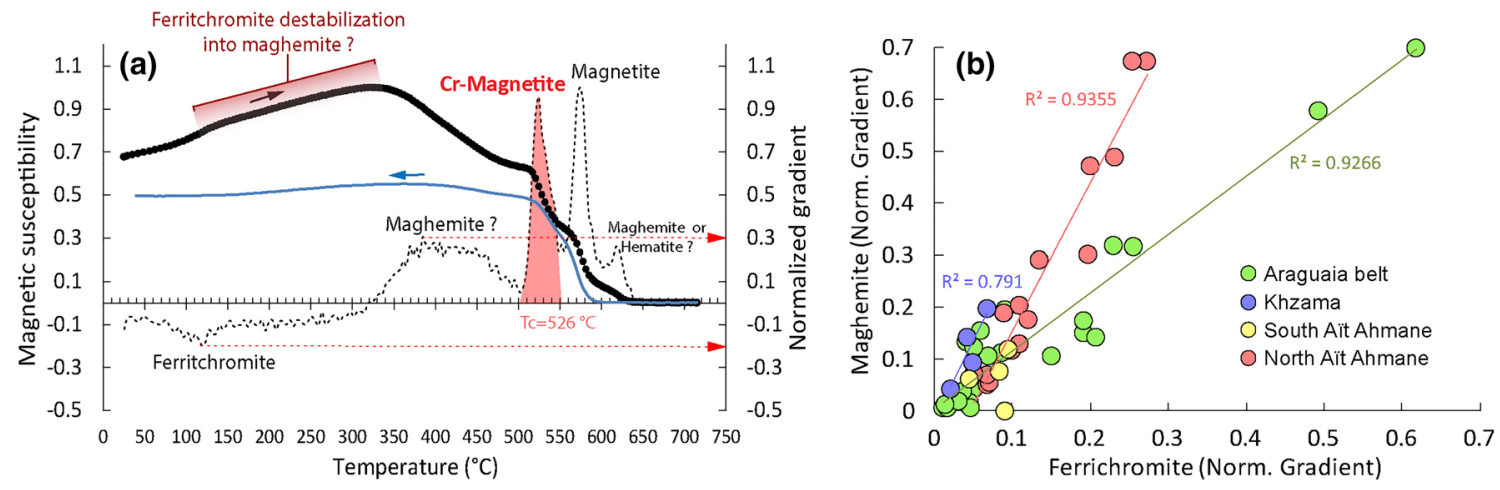

Figure 4. (a) Thermomagnetic curves (sample AA0101F from the North Aït Ahmane unit) with a Curie point at $526^{\circ} \mathrm{C}$ characteristic of $\mathrm{Cr}$-magnetite. The destabilization of ferritchromite in maghemite from $130^{\circ} \mathrm{C}$ is also visible. The dotted curve corresponds to the normalized gradient of the magnetic susceptibility heating curve, making it possible to quantify the relative contribution of each magnetic species to the susceptibility (red dotted arrows). (b) Maghemite contribution to the magnetic susceptibility against that of the ferritchromite (normalized gradient of ferritchromite is expressed in absolute value for a better readability). Linear correlation attests to the link between these two magnetic species. Interestingly, slopes vary for the different units. It might attest to a different alteration pattern. "Norm. gradient" of the magnetic susceptibility curve corresponds to peak values reached by the normalized prime derivative of the heating curve in heating $\left[\left(K T_{t+1}-K T_{t}\right) /\left(T_{t+1}-T_{t}\right)\right]$ for the temperature range of ferritchromite and maghemite destabilization.

maximum. These increases are not reversible, while the rest of the curves are almost reversible. The first decrease in magnetic susceptibility continues until between 400 and $450^{\circ} \mathrm{C}$. Then, the curves are generally stable up to $500^{\circ} \mathrm{C}$ (Figure 4a). These two transitions are tentatively associated with ferritchromite destabilization and its partial conversion into maghemite which is then thermally destabilized from ca. $320^{\circ} \mathrm{C}$ (e.g., Hodel et al., 2017; Horen et al., 2014). To investigate if these features that appear during heating could represent fingerprints of alteration processes, we estimated the gradient of these two steps, the increase and the decrease in magnetic susceptibility centered around $300-350^{\circ} \mathrm{C}$. We plotted the peak values of the gradients associated with ferritchromite and maghemite against each other. Interestingly, there is a strong linear correlation between these two magnetic signals (Figure $4 b$ ).

At higher temperatures, curves present either one or two marked transitions at $515 \pm 11^{\circ} \mathrm{C}$ (ranging from 504 to $526^{\circ} \mathrm{C}$ for our sampling) and ca. $580^{\circ} \mathrm{C}$, corresponding respectively to the Curie points of Cr-magnetite and pure magnetite (Figures 4-6). The concomitant presence of these two Curie points is only noticeable in the serpentinites with strongly altered spinels of the North Aït Ahmane unit. The $515 \pm 11^{\circ} \mathrm{C}$ transition is never found in samples from the South Aït Ahmane and Khzama units, and rarely in the Araguaia Belt except for sample QT73. All samples from these serpentinites with weakly altered spinels display the Curie
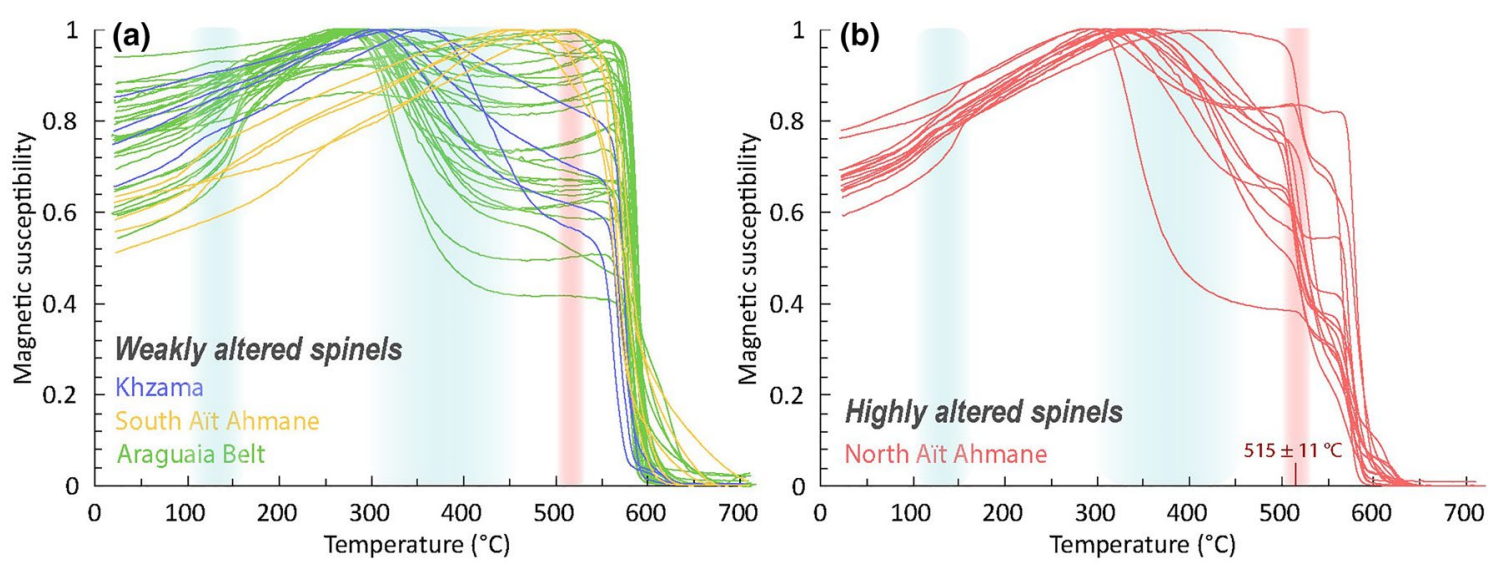

Figure 5. Thermomagnetic curves (heating only) of bulk serpentinite samples from the four studied ultramafic units. (a) Serpentinites hosting weakly altered Cr-spinels: Araguaia Belt, Khzama, and South Aït Ahmane units, (b) Serpentinites hosting highly altered Cr-spinels: North Aït Ahmane units. Most of the curves display several mineralogical transformations (highlighted by blue and red shaded rectangles), around $130,300-450,515 \pm 11$, and $580^{\circ} \mathrm{C}$. Note that only North Aït Ahmane serpentinites show a Curie point around $515^{\circ} \mathrm{C}$. 


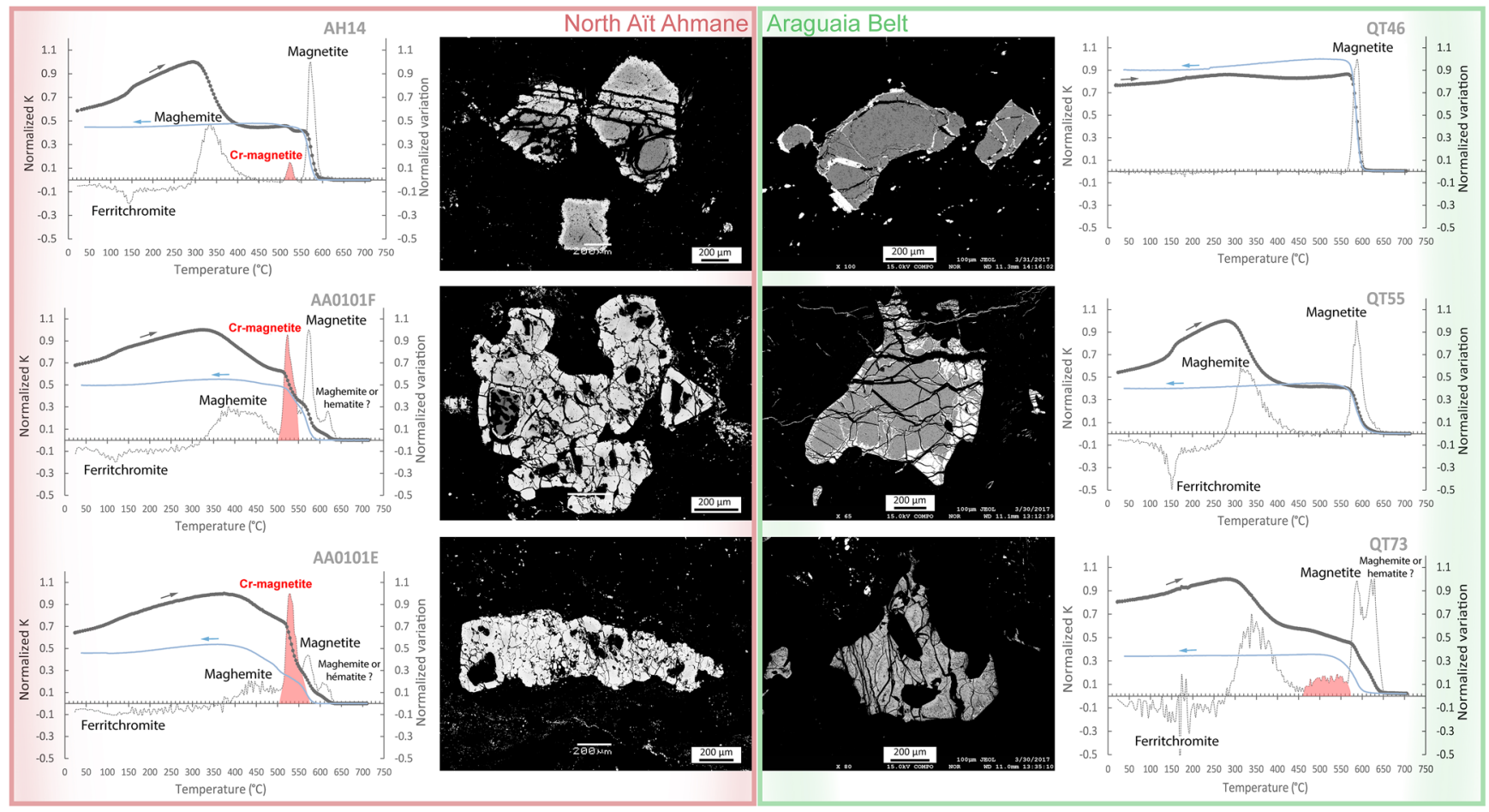

Figure 6. Thermomagnetic curves of bulk serpentinites samples and backscattered electrons microphotographs of typical spinels of the corresponding samples from strongly altered spinels from the North Aït Ahmane (Morocco), compared to weakly altered spinels from the Araguaia Belt ultramafic units (Brazil). The dashed line corresponds to the normalized gradient of the thermomagnetic curves (during heating) that is used to quantify the relative contribution of each magnetic species to the total magnetic susceptibility.

point of near-pure magnetite ca. $580^{\circ} \mathrm{C}$ (Figures 5 and 6). We occasionally notice a higher $T_{\mathrm{c}}$, concerning a minor part of the total magnetic susceptibility, which likely corresponds to small amounts of hematite (e.g., in samples QT73 and AA0101F, E, see Figure 6) or a remaining maghemite phase (Gehring et al., 2009).

Low-temperature susceptibility curves (Figure 7) highlight the magnetic transitions below ambient temperature. Two samples of serpentinites from the North Aït Ahmane unit have been selected for these analyses: AH14 and AA0101E, representing respectively weakly altered (Figures 2g and 2j) and strongly altered
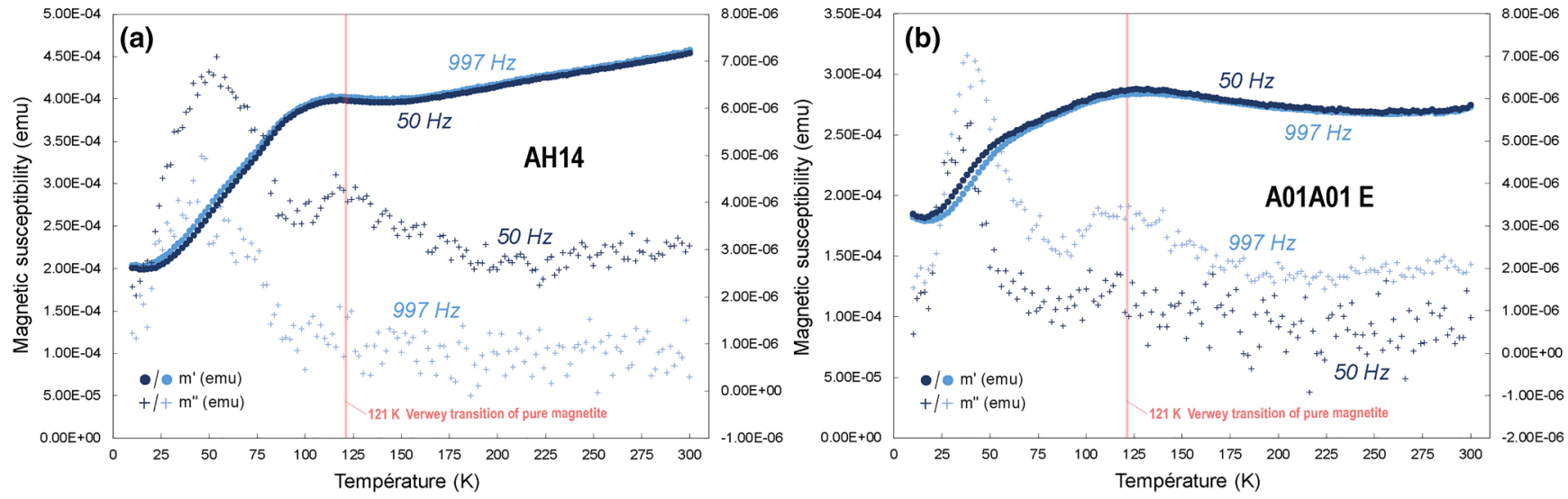

Figure 7. In-phase ( $\left.\mathrm{m}^{\prime \prime}\right)$ and out-of-phase (") magnetic susceptibility measurements at low temperature for two serpentinites of the North Aït Ahmane ultramafic unit: (a) sample AH14 whose spinels are weakly altered and (b) sample AA0101E whose spinels are most of the time completely replaced by ferritchromite and Cr-magnetite. 


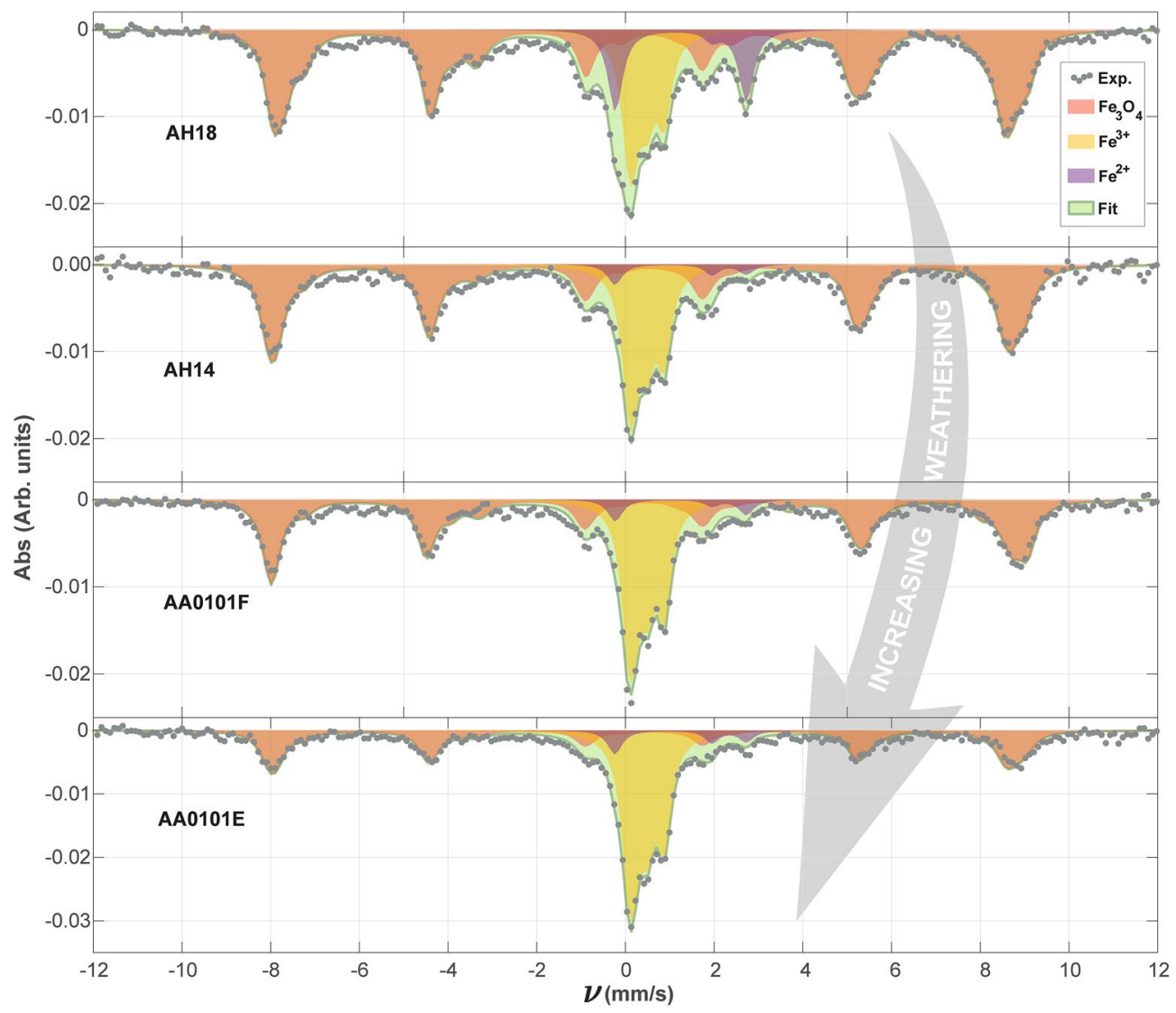

Figure 8. Mössbauer spectra collected at $80 \mathrm{~K}$. Dots: experimental data; green line and area: global computed curve; colored areas: elemental components. The gray arrow illustrates the increasing hydrothermal alteration of these serpentinites and of their constitutive spinels.

spinels (Figures $2 \mathrm{i}$ and 2l). In both samples, a magnetic transition is observed around $120 \mathrm{~K}$ and corresponds to the Verwey transition of magnetite (Figure 7). This transition is wider and shifted toward lower temperatures for the more altered sample AA0101E (Figure 7b). This behavior is classically attributed to a higher amount of Fe substitution in magnetite or oxidation (Barlow et al., 1987; Özdemir et al., 1993). Another transition is clearly visible toward $40-50 \mathrm{~K}$ for the two samples. It appears at slightly higher temperature and is wider in sample AH14 (Figure 7a) than in sample AA0101E (Figure 7b). A similar transition with temperatures varying from 38 to $100 \mathrm{~K}$ has been identified in synthetic $\mathrm{Cr}$-Fe-spinels nanoparticles with different amounts of $\mathrm{Cr}$ and was interpreted as a result of the compositional and grain-size dependence of the blocking temperature in these very fine magnetic particles (e.g., Sandu et al., 2017).

\subsection{Mössbauer Characterization}

Mössbauer spectra were measured for four samples from the North Aït Ahmane unit at 80 K (Figure 8). Variations between samples seem related to the degree of alteration. The two spectra of samples containing little Cr-magnetite, hence showing weak alteration state, display characteristic magnetite fine structures. The spectra can be fitted with the five characteristic components of natural magnetite below the Verwey transition (Doriguetto et al., 2003). Upon alteration, the magnetite fraction decreases, while the paramagnetic $\mathrm{Fe}^{3+}$ content grows up. Also, the magnetite spectra progressively round up, and only four of the five components are useful for the fitting. For the central paramagnetic components, the main absorption peaks stay in the same position. The spectra were then analyzed with a set of five paramagnetic contributions. These signatures are in agreement with those identified in lizardite materials (O'Hanley and Dyar 1993) and other ferritchromite materials (Lenaz et al., 2004). 


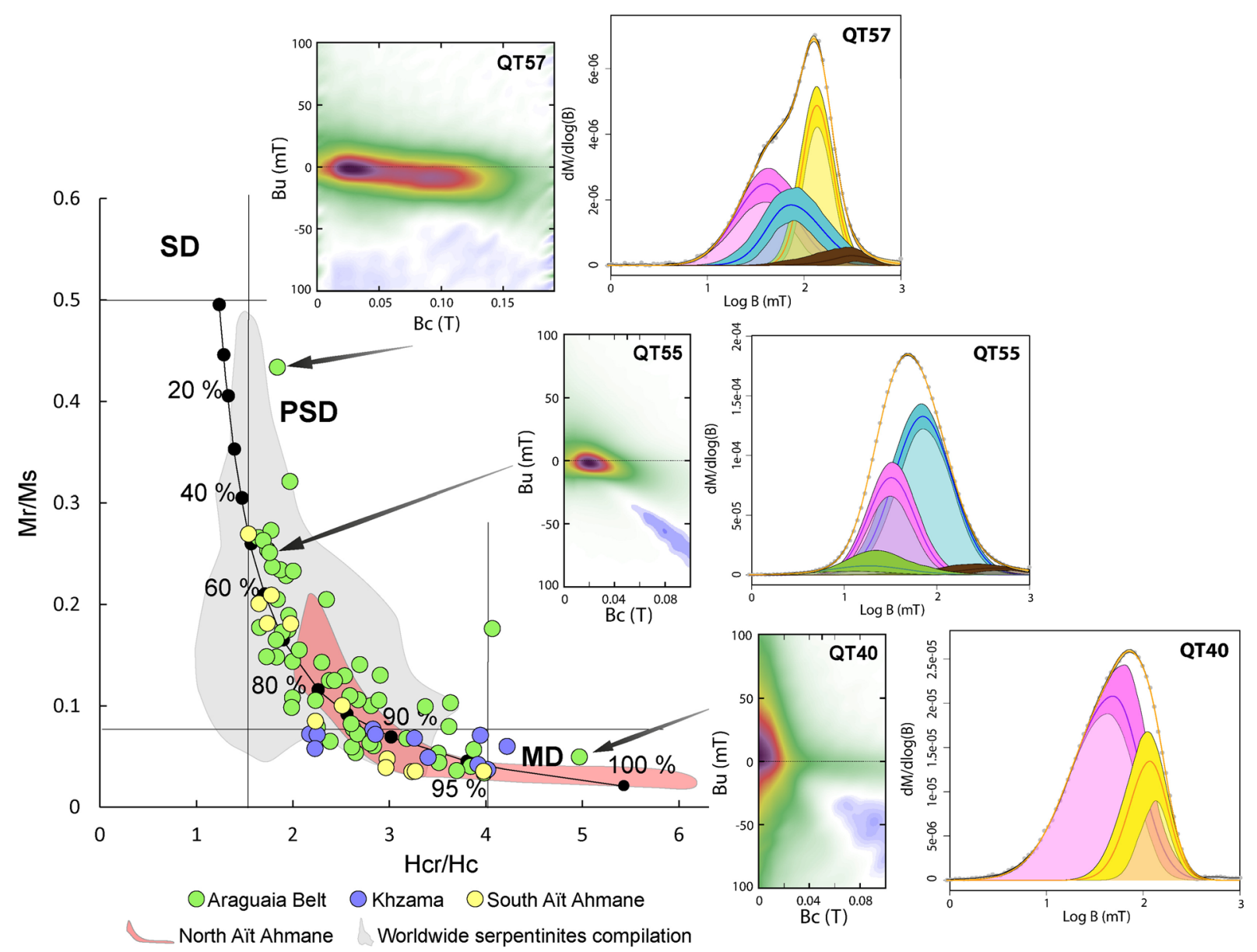

Figure 9. Representation of hysteresis parameter ratios in a Day diagram (Day et al., 1977) for serpentinites from Araguaia Belt, Khzama, and South Aït Ahmane ultramafic units. The different areas bounded by the black lines represent areas of different grain sizes, from the smallest to the coarsest: SD for a single domain, PSD for pseudo-single domains, and MD for multi-domains. The black curve is a theoretical mixing curve between SD and MD magnetite grains, the percentages corresponding to the MD fraction (Dunlop, 2002b). The red field is that of hydrothermalized serpentinites from the North Ait Ahmane unit, the most altered falling always into the MD domain (from Hodel et al., 2017). The gray field on the diagram corresponds to literature data for serpentinites and serpentinized peridotites from Bonnemains et al. (2016), Fujii et al. (2016), Maffione et al. (2014), and Oufi et al. (2002), FORC diagrams (in the middle) and IRM curves deconvolutions (right) of the Araguaia Belt serpentinites also depict how the grain size evolves through the diagram for the less altered serpentinites. FORC, first-order reversals curves; IRM, isothermal remanent magnetization.

\subsection{Hysteresis and Magnetic Granulometry}

Results of magnetic hysteresis analyses carried out on serpentinites from the four studied ophiolitic units are given in Data Set S4.

Hysteresis parameters provide an initial assessment of the grain size of the magnetic grain populations. These parameters are conventionally represented in a Day diagram (Day et al., 1977; Dunlop, 2002a, 2002b) in which different areas represent different domain states of magnetite and Ti-magnetite (Dunlop, 2002a, 2002b) including single-domain (SD), pseudo-single domain (PSD) and multi-domain (MD) grains, from the smallest to the coarser (Figure 9). All samples plot near the theoretical mixing line of the mixture of SD and MD magnetites (Dunlop, 2002b) (Figure 9). However, it is important to mention that this diagram does not distinguish mixtures of grains with different sizes (i.e., domain states).

All samples with weakly altered spinels show magnetic hysteresis properties comparable to those of other serpentinites previously reported in the literature (e.g., Bonnemains et al., 2016; Fujii et al., 2016; Maffione et al., 2014; Oufi et al., 2002) (gray shadow in Figure 9). Serpentinites from the Brazilian ultramafic units of the Araguaia Belt exhibit a wide variation of magnetic grain sizes with $M_{\mathrm{rs}} / M_{\mathrm{s}}$ and $H_{\mathrm{cr}} / H_{\mathrm{c}}$ ratios between 0.03 and 0.43 and 1.62 and 4.3, respectively. The only exception is again the sample QT40 with a $H_{\mathrm{cr}} / H_{\mathrm{c}}$ ratio 
of 4.92, which corresponds to a spinel rich serpentinized dunite (Figure 9). Similarly, the South Aït Ahmane and Khzama units of the Moroccan serpentinites display hysteresis parameters mostly into the PSD domain (Figure 9), the serpentinites of South Aït Ahmane showing a wider magnetic grains size range than those of the Khzama ophiolite, with $M_{\mathrm{rs}} / M_{\mathrm{s}}$ ratios varying between 0.04 and 0.27 and 0.04 and 0.08 , respectively, and $H_{\mathrm{cr}} / H_{\mathrm{c}}$ ratios between 1.53 and 3.97 and 2.16 and 4.21, respectively. In contrast, serpentinites from the North Aït Ahmane unit (indicated by the red shadow in Figure 9) exhibit much coarser grain sizes occupying entirely the MD field in the Day diagram.

To better constrain the magnetic grain size distributions (Figure 9), we performed IRM and FORC acquisitions on the Brazilian serpentinites of the Araguaia Belt. IRM curves and FORCs denote the presence of SD, PSD, and MD grains in these samples (Figure 9). Statistical analysis of IRM acquisition curves (Maxbauer et al., 2016) displays two to four distinctive magnetic components with variable contributions to the total IRM. When necessary, we add skewness to obtain the best fit. The main populations are characterized by moderate to high coercivities (mean coercivity from 1.5 to 2) that probably reflect a mixture of MD and SD/PSD magnetites. Sample QT57 with the highest $M_{\mathrm{rs}} / M_{\mathrm{s}}$ ratio (0.43) is composed of four populations of magnetic oxides (Figure 9). It exhibits a predominant population of magnetite with high coercivities. This corroborates the predominance of SD/PSD magnetites in weakly altered samples. The contribution of the moderate coercivities population increases with the alteration. Hematite is sometimes detected in samples with larger magnetite grain sizes (e.g., in samples QT73 and AA0101F, E). However, this contribution to the total IRM remains minor.

In FORC diagrams, samples with intermediate $M_{\mathrm{rs}} / M_{\mathrm{s}}$ and $H_{\mathrm{cr}} / H_{\mathrm{c}}$ ratio (e.g., sample QT55) show a typical single-domain behavior with a ridge along with the origin and relatively high $H_{c}$ values whereas sample QT40 displays well-expressed low-moderate coercivity components on the IRM curves and FORC diagram characteristic of MD magnetic grains, with a wide vertical distribution close to the origin and relatively low $H_{\mathrm{c}}$ values.

\subsection{Magnetic Scanning Microscopy}

We performed magnetic microscopic scans on Cr-spinel grains displaying alteration rims in order to investigate the magnetization of the Cr-spinel's alteration products. Figure 10 shows the perpendicular component of the magnetic field response to $35 \times 35 \mathrm{~mm}$ and $15 \times 15 \mathrm{~mm}$ scans of a thin section of the North Aït Ahmane sample AA0101F. The $35 \times 35 \mathrm{~mm}$ map highlights the scattered distribution of magnetic minerals in the serpentine matrix. A higher magnification image (Figure 10c) emphasizes magnetic zonation in highly altered spinel grains, with an increasing magnetization from partially preserved spinel cores toward the strongly magnetic ferritchromite Cr-magnetite rims. Comparison between SEM observations (BSE image and elemental maps) and magnetic maps clearly shows that the preserved pristine spinel core $(\mathrm{Cr}$ and $\mathrm{Al}$ rich zone in Figures $10 \mathrm{~h}$ and 10i) shows much weaker magnetization compared to the altered Fe-rich rims. Thus, magnetic scanning makes it possible to reveal the scale of the magnetization intensity corresponding to ferritchromite and Cr-magnetite at the grain level. Moreover, a punctual hysteresis curve performed on the spinel grain's alteration rim using the magnetic scanning microscope (Figure 10d) exhibits low coercivity typical of magnetite. This attests that Cr-magnetite's magnetic behavior is very similar to that of pure magnetite. Another punctual hysteresis curve for which saturation is not reached testifies to the presence of hematite (Figure 10e).

\section{Discussion}

All the measurements and observations performed in this study tend to dissociate the North Aït Ahmane serpentinites from the three other units (Araguaia Belt, Khzama, and South Aït Ahmane) in terms of petrography, chemistry of Cr-spinel alteration phases and magnetic mineralogy.

Petrographical observations indicate that the spinels of the North Aït Ahmane serpentinites are mostly highly altered compared to their counterparts from the other three units (Figure 2). Spinels of the North Aït Ahmane serpentinites are rimmed by a wide range of $\mathrm{Cr}$-Fe minerals that, in extreme cases, entirely replace the pristine spinel cores (Figures $2 \mathrm{~g}-2 \mathrm{l}$ ). On the contrary, other serpentinites host spinels only partially replaced by sharp and weakly developed Cr-Fe mineral rims (Figures 2a-2e). 


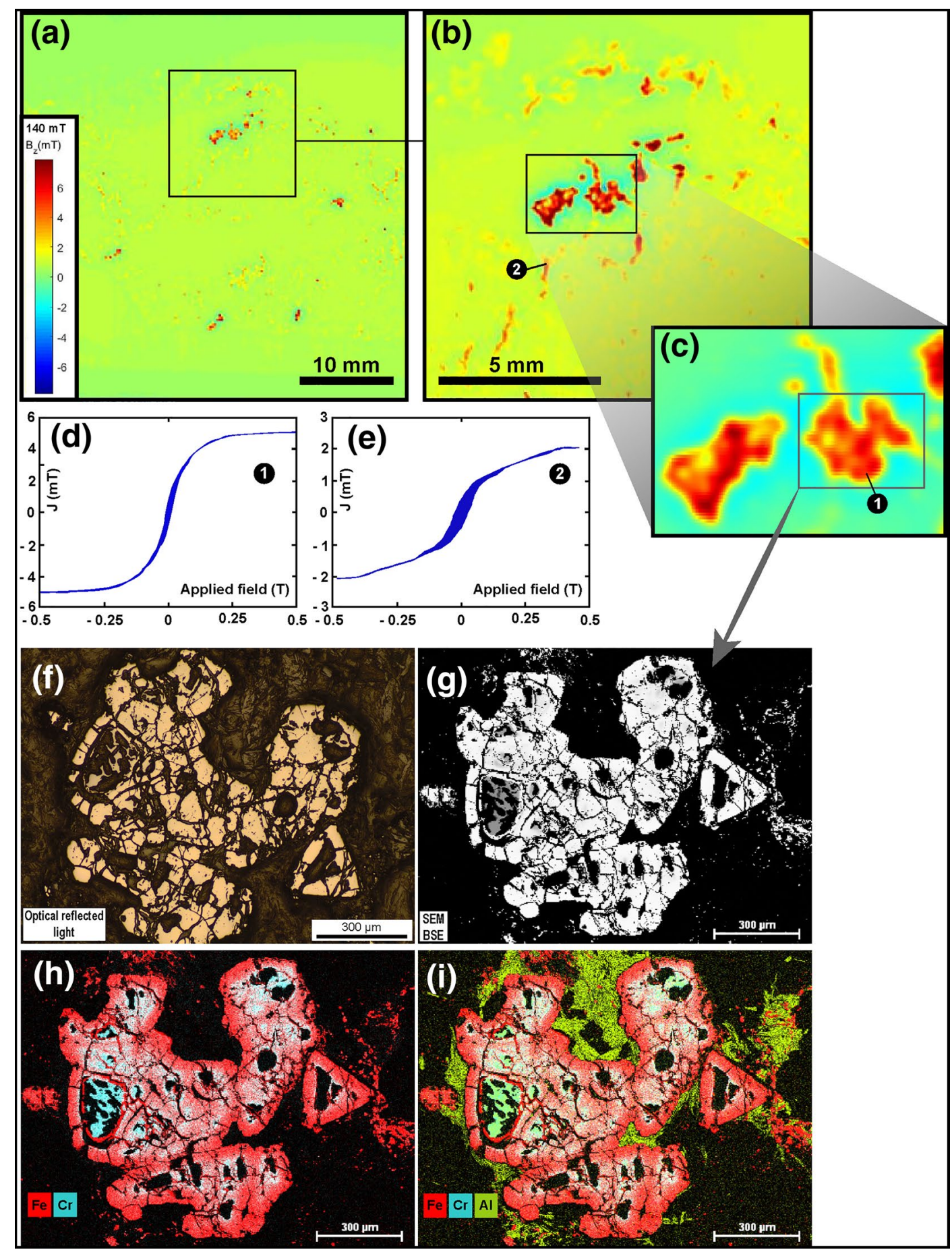

Figure 10. (a-c) Magnetic maps using magnetic scanning microscopy showing the induced magnetization into a highly hydrothermalized sample from the North Aï Ahmane unit (AA0101F). As described by Hodel et al. (2017) serpentinization related magnetite is less present in these samples. Magnetization is partly carried by the Cr-magnetite resulting from $\mathrm{Cr}$-spinel grains alteration. ( $\mathrm{d}$ and e) Punctual hysteresis measurements for points 1 and 2 in $\mathrm{c}$ and b, respectively. (f) Corresponding microphotograph of a highly altered spinel grain. (g) BSE image of the same grain. (h and i) SEM elemental mapping of the same grain ( $\mathrm{Fe}, \mathrm{Cr}$ in $\mathrm{h}$ and $\mathrm{Fe}, \mathrm{Cr}, \mathrm{Al}$ in i). $\mathrm{Cr}$ - and $\mathrm{Al}$-rich parts correspond to preserved and partially preserved spinel cores while Fe-richer phases (in red) are ferritchromite and Cr-magnetite. 
These alteration products also differ in terms of chemistry. Sharp alteration rims of the Araguaia Belt, Khzama and South Aït Ahmane serpentinite mostly consist either of ferritchromite which rarely show $\mathrm{Cr}_{2} \mathrm{O}_{3}$ content below 13 wt.\% or magnetite containing less than 5 wt.\% of $\mathrm{Cr}_{2} \mathrm{O}_{3}$. In contrast, North Aït Ahmane serpentinites display a complete range of $\mathrm{Cr}$-Fe minerals composition, which nevertheless never show $\mathrm{Cr}_{2} \mathrm{O}_{3}$ content below 9.70 wt.\% (Figure 3a).

Magnetic measurements also point out the major differences between the North Aït Ahmane serpentinites and those from the three other units. For all units, thermomagnetic curves evidence several magnetic minerals related to $\mathrm{Cr}$-spinel alteration in addition to the magnetite produced by the serpentinization reaction (Figure 5). Among these magnetic minerals, one showing a $T_{\mathrm{c}}$ at $515 \pm 11^{\circ} \mathrm{C}$ (Figure $5 \mathrm{~b}$ ) as well as a widening of the Verwey transition near $121 \mathrm{~K}$ (Figure 7), is exclusive to the North Aït Ahmane serpentinites. While serpentinites from the Araguaia Belt, Khzama and South Aït Ahmane contain a mixture of PSD and MD grains characterized by $H_{\mathrm{cr}} / H_{\mathrm{c}}$ ratios below four, as commonly observed in serpentinites worldwide, those from the North Aït Ahmane host coarser MD magnetic grains with $H_{\mathrm{cr}} / H_{\mathrm{c}}$ ratios reaching six (Figure 9). Below, we discuss the particular magnetic features of the different $\mathrm{Cr}$-spinel alteration products in the studied serpentinites. We compare them with mineral chemistry and Mossbauer spectroscopy results to better constrain their nature as well as the processes involved in their formation.

\subsection{Magnetic Identification of Cr-Magnetite}

The North Aït Ahmane serpentinites differ from others by displaying two $T_{\mathrm{c}} \mathrm{s}$ in the thermomagnetic curves (Figures 4-6). In addition to the pure magnetite $T_{\mathrm{c}} \mathrm{ca} .580^{\circ} \mathrm{C}$, they present a $T_{\mathrm{c}}$ at $515 \pm 11^{\circ} \mathrm{C}$ (Figure $5 \mathrm{~b}$ ). They also show a widening of the Verwey transition in low-temperature magnetometry (Figure 7). These two features correspond to a typical signal of magnetite containing impurities, $\mathrm{Cr}$ in this case. Indeed, the presence of $\mathrm{Cr}$ in the crystalline lattice of magnetite results in a decrease of the Verwey transition (initially at $121 \mathrm{~K}$ for pure magnetite) or to the suppression of the latter passing from an inverse spinel to monoclinic structure during cooling (Gattacceca et al., 2011). This Cr-rich magnetite, detected only in the serpentinites of the North Aït Ahmane unit hosting highly altered Cr-spinels, is thus likely to be a spinel alteration product (Figures 5 and 6).

Hysteresis parameters denote unusually large magnetic grains in North Aït Ahmane serpentinites (Figure 9, Hodel et al., 2017). Hodel et al. (2017) proposed that these coarser magnetite grains likely correspond to $\mathrm{Cr}$-spinel alteration products, notably Cr-magnetite. This is confirmed by our magnetic scanning microscope observations showing that altered spinel grains carry strong magnetization, with a magnitude similar to that of pure magnetite produced by sea-floor serpentinization (Figure 10). Electron microprobe analyses reveal that these large magnetic grains correspond to a wide range of $\mathrm{Fe}-\mathrm{Cr}$ oxides replacing $\mathrm{Cr}$-spinel grains (Figures $2 \mathrm{~g}-2 \mathrm{l}$ and 6 ). These $\mathrm{Fe}-\mathrm{Cr}$ oxides contain up to $86.10 \mathrm{wt} . \%$ of $\mathrm{FeO}_{\mathrm{T}}$, which corresponds to a $n$ of 0.15 in the structural formula of the series, $\left.\mathrm{Fe}^{2+}\left(\mathrm{Fe}_{1-n} \mathrm{Cr}_{n}\right)_{2} \mathrm{O}_{4}\right)$ (Figure 1). A value of $n=0.15$ would theoretically correspond to a $T_{\mathrm{c}}$ of $478^{\circ} \mathrm{C}$ (Figure 1) in the model of Ziemniak and Castelli (2003), which is lower than the one we measured in our samples from North Aït Ahmane. Indeed, the $T_{\mathrm{c}}$ at $515 \pm 11^{\circ} \mathrm{C}$ that we observe is supposed to correspond to a $n$ between 0.085 and 0.114 in the cited model.

Interestingly, Kądziałko-Hofmokl et al. $(2008,2010)$ also observed a "double magnetite $T_{\mathrm{c}}$ " in the range $500-580^{\circ} \mathrm{C}$ in the Devonian serpentinites of the Grochowiec unit (Braszowice-Brzeźnica ophiolite, Poland), with a $T_{\mathrm{c}}$ of ca. $530^{\circ} \mathrm{C}$, similar to those observed in the serpentinites of the North Aït Ahmane unit. These authors also interpreted this $T_{\mathrm{c}} \mathrm{ca} .530^{\circ} \mathrm{C}$ as reflecting the presence of Cr-magnetite. As in the case of North Ait Ahmane spinels, the $n$ measured for spinel's alteration products in the Grochowiec serpentinites is always greater than 0.1 (Figure 3b). It is also important to note that Kądziałko-Hofmokl et al (2010) describe another unit (the Mnich unit) which contains phases with $n$ values between 0 and 0.1 (i.e., greater amount of iron). This one only displays the Curie point of pure magnetite ca. $580^{\circ} \mathrm{C}$, as it is the case for the serpentinite units hosting weakly altered spinels in the present study (i.e., Araguaia Belt, Khzama, South Aït Ahmane) (Figures 2a-2e, 3a, and 5a).

The compositions that we measured in alteration rims of spinels of the North Aït Ahmane serpentinites are very similar to those measured in the Grochowiec serpentinites by Kądziałko-Hofmokl et al. (2010) (Figure 3). According to these analyses, the magnetic phase having a Curie point at $515 \pm 11^{\circ} \mathrm{C}$ in North 


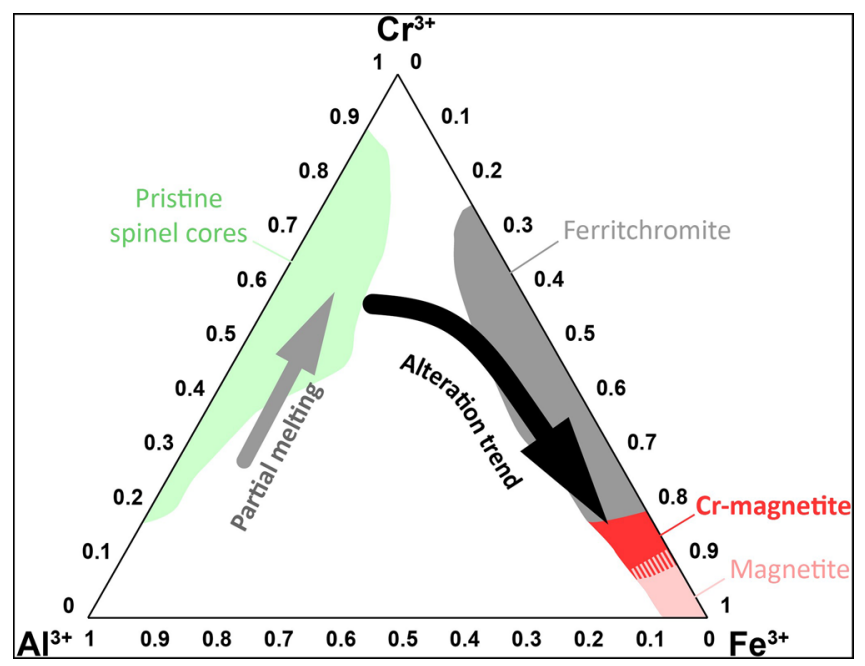

Figure 11. Triangular diagram of concentrations of trivalent cations $\mathrm{Al}^{3+}$, $\mathrm{Cr}^{3+}$, and $\mathrm{Fe}^{3+}$ illustrating the domains of the composition of the different $\mathrm{Cr}$-Fe-spinels produced by mantle spinels alteration after Ahmed and Surour (2016) and Barnes and Roeder (2001). We specify the composition field for Cr-magnetite.
Aït Ahmane serpentinites, and ca. 530 for Grochowiec serpentinites (Kądziałko-Hofmokl et al., 2010) corresponds to a $\mathrm{Cr}$-Fe-spinel having $n$ between 0.1 and 0.2 (i.e., a $\mathrm{Cr}_{2} \mathrm{O}_{3}$ content between about 6 and 13 wt.\%) (Figures 3 and 11). The less chromiferous Fe-rich spinel phases $(n<$ 0.1, i.e., $\mathrm{Cr}_{2} \mathrm{O}_{3}<5$ wt. \%) observed in the North Aït Ahmane and also in the other serpentinites from Araguaia, Khzama and South Aït Ahmane do not seem to have a Curie point distinguishable from that of pure magnetite or, alternatively, their signal is masked by the high susceptibility of the pure magnetite produced by the serpentinization reactions (Figures 3 and 11). Providing a more precise interval of $n$ values than $0.1<n<0.2$ for the $\mathrm{Cr}$-magnetite is challenging and could be achieved only through an experimental approach. Indeed, in natural samples the measured $T_{\mathrm{c}}$ corresponds to that of a mixing of different Cr-magnetites. Cr-magnetite becomes richer in iron from the cores toward the rim of altered spinel grains. This is reflected by the change in magnetization intensity in the scanning magnetic maps. The proportion of Fe-richer $\mathrm{Cr}$-magnetite versus $\mathrm{Fe}$-poorer $\mathrm{Cr}$-magnetite varies for each spinel grain to another according to its morphology, fracturation, exposition to more or less acid and oxidizing fluid, making it impossible to better constrain the Cr-magnetite composition within each sample.

The different magnetic methods that we have used here highlight the similarity of the magnetic properties of Cr-magnetite (as defined here) and pure magnetite, with the exception of the $T_{\mathrm{c}} \mathrm{s}$. At microscopic scale, the innovative scanning magnetic maps, allowing both the estimation of the induced magnetization changes at grain scale and their hysteresis curves, permit to directly compare these parameters to chemistry data at the same scale. This makes this innovative technique promising for further studies.

Taken together, our observations provide better constraints on the Cr-magnetite composition domain generally used in studies treating the chemistry of spinels and their alteration products, initially based on the work of Barnes and Roeder (2001). Fe-rich Cr spinels with a $n$ greater than 0.2 are non (easily) detectable by their magnetic signature. Those with a $n$ lower than 0.1 appear indistinguishable from pure magnetite. We thus propose a new definition for the Cr-magnetite: a Fe-rich Fe-Cr spinel with a $n$ between 0.1 and 0.2 (Figure 11) that could carry a strong magnetization and a $T_{\mathrm{c}}$ at ca. $500-530^{\circ} \mathrm{C}$, distinguishable from that of pure magnetite.

\subsection{The Ferritchromite Signal in Thermomagnetic Curves}

In most of the studied samples, ferritchromite is evidenced by a specific thermomagnetic signature that consists of a sudden increase of magnetic susceptibility between 130 and $150^{\circ} \mathrm{C}$ during the first heating (Figures 4-6). This likely corresponds to a chemical transformation due to the destabilization of ferritchromite phases (Hodel et al., 2017; Horen et al., 2014). This sudden increase continues with a milder increase up to $300-400^{\circ} \mathrm{C}$ forming a bulge that does not remain during cooling. This indicates the formation of a new phase which is then transformed again at higher temperatures (Figures 4-6). Except for this bump, curves are generally almost reversible, that is, they regain almost the same magnetic susceptibility value when they return to room temperature (Figures 5 and 6). This clearly indicates a transformation of a paramagnetic phase into a magnetic phase that destabilizes itself into a non-magnetic or weakly magnetic phase over $350-400^{\circ} \mathrm{C}$. Hodel et al. (2017) proposed that this particular trend should be due to the transformation of paramagnetic ferritchromite into a transitional phase, possibly maghemite. Indeed, the shape of the bulge and the destabilization temperature are characteristic of maghemite (e.g., Gehring et al., 2009). Such a transformation could be linked to oxidation leading to cation mobility in the different sites by dynamic segregation (e.g., Domenichini et al., 2002; Horen et al., 2014). Otherwise, the transition visible at 40-50 K on the low-temperature magnetic susceptibility curves (Figure 7) could correspond to chromite as described by Gattacceca et al. (2011) in ordinary chondrite.

When plotted together, values of the normalized gradient of heating curves of the ferritchromite destabilization versus these of maghemite destabilization (Figure 4b) display linear correlations. Interestingly, trends 


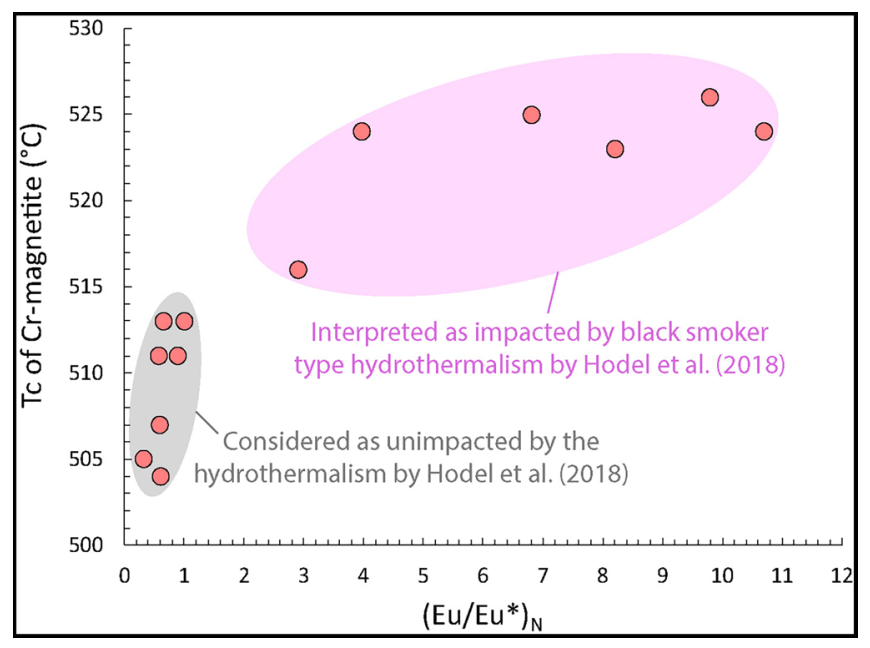

Figure 12. Graphical representation of the measured $T_{\mathrm{c}}$ of Cr-magnetite versus $\left(\mathrm{Eu} / \mathrm{Eu}^{*}\right)_{N}$ ratio. The $\left(\mathrm{Eu} / \mathrm{Eu}^{*}\right)_{N}$ corresponds to $\mathrm{Eu} /[(\mathrm{Gd}+\mathrm{Sm}) / 2]$ normalized to the chondrite (Barrat et al., 2012) and quantifies the Eu positive anomaly produced by abyssal hydrothermalism in the serpentinites. $\left(\mathrm{Eu} / \mathrm{Eu}^{*}\right)_{N}$ ratios values are from Hodel et al. (2018). are different for the different serpentinite units implying the maghemite resulting from the destabilization of ferritchromite is specific to each unit of serpentinites. For instance, more maghemite seems to be produced following the destabilization of a given amount of ferritchromite in the case of the North Aït Ahmane serpentinites compared to the Araguaia belt serpentinites (Figure 4b). This is probably linked with the composition of the ferritchromite itself. Hence, these differences in covariation of ferritchromite versus maghemite thermomagnetic signals could attest different alteration patterns and hence different alteration processes.

\subsection{A Way to Decipher Cr-Spinel Alteration Processes}

Here we show that magnetic methods can help to characterize the alteration processes that a given spinel-bearing rock has endured. Chemical composition and magnetic properties of spinel alteration products, namely ferrichromite and Cr-magnetite, which show wide ranges of geochemical variability governed by $\mathrm{Fe}-\mathrm{Cr}$ substitutions, are closely controlled by the nature of the involved metamorphism (e.g., P, T, fluid, etc., e.g., Ahmed \& Surour, 2016; Barnes, 2000; Hodel et al., 2017; González-Jiménez et al., 2009). Hence, the magnetic detection of the different spinel alteration products, the quantification of their relative abundance and the assessment of their chemical variability allow to partially reconstruct the alteration history of a given rock sample.

Advanced spinel alteration, is generally associated with high metamorphic grade, involving temperatures of $500-600^{\circ} \mathrm{C}$ or higher (e.g., Ahmed \& Surour, 2016; Barnes, 2000; González-Jiménez et al., 2009; Mellini et al., 2005). However, the North Aït Ahmane serpentinites, which endured much lower temperatures (below $300^{\circ} \mathrm{C}$, Hodel et al., 2017, 2018), host highly altered spinels showing a wide range of ferritchromite and Cr-magnetite compositions (Figures 2g-2l and 3a). As presented in detail in Hodel et al. (2017, 2018), serpentinites from the North Aït Ahmane unit were variously impacted by abyssal hydrothermalism leading to important $\mathrm{Cr}$-spinel alteration. Interestingly, $T_{\mathrm{c}}$ of $\mathrm{Cr}$-magnetite measured in these serpentinites is highly correlated to the intensity of their hydrothermal signature as quantified by the $\left(\mathrm{Eu} / \mathrm{Eu}^{*}\right)_{N}$ ratio (see Hodel et al., 2018) (Figure 12). Such correlation is likely to be due to enhanced Fe-Cr substitutions, promoted by warm (ca. $280^{\circ} \mathrm{C}$ ), acidic and oxidizing fluids (Hodel et al., 2017, 2018). This produces greater amounts and Fe-richer Cr-magnetite rims around spinel grains compared to less affected serpentinite. This brings new evidence concerning the link between the hydrothermal episode endured by the North Aït Ahmane serpentinites and intense spinel alteration despite the relatively low temperatures of these processes (Hodel et al., 2017, 2018).

In addition to the magnetic evidence, cation exchanges under oxidizing conditions induced by abyssal hydrothermalism $\left(T<300^{\circ} \mathrm{C}\right)$ are also evidenced by Mossbauer spectroscopy, which clearly attests changes in the iron oxidation state with increasing weathering (Figure 8).

Conversely to North Aït Ahmane, serpentinites of the South Aït Ahmane and Khzama units, which experienced higher temperature $\left(>350^{\circ} \mathrm{C}\right)$ and do not show major hydrothermal imprint, host only very weakly altered spinels (Figures 2c-2f).

Therefore, in addition to temperature, spinel alteration also appears to be controlled by the type of metamorphic event endured by their host rocks, notably when important amounts of fluids are involved (e.g., Barra et al., 2014). In this case, the fluid-rock ratio, as well as the physico-chemical properties of the fluid, could also play a key role in the spinel alteration. Particularly, the fluid redox state (oxidizing conditions favoring trivalent cations mobility), its $\mathrm{pH}$ (acidic $\mathrm{pH}$ promoting transition metals mobility) but also anionic ligands availability (the latter allowing transition metals mobility as well) have to be considered (Holser \& Schneer, 1961; Kalczynski \& Gates, 2014; Purtov et al., 1989). Significant spinel alteration (major to complete obliteration of the primary spinel by Cr-magnetite and ferritchromite), associated to evidence of low 
metamorphic conditions (e.g., $T<350^{\circ} \mathrm{C}$ ), likely constitutes a good indicator of significant hydrothermal activity.

Hence, this study shows that phases produced by spinel alteration processes can be easily tracked with magnetic methods. As seen before, each of the four units studied here display its proper magnetic fingerprint (Figures 4-6 and 9). We show that thermomagnetic curves constitute a prime method to (1) identify the products of Cr-spinel alteration (ferritchromite, Cr-magnetite), (2) assess the different chemical compositions of these phases (e.g., Figures $4 \mathrm{~b}$ and 12), and (3) quantify their relative contribution to the magnetization, and so their relative abundance in a given sample. Hence, this study opens the door to the use of magnetic methods to investigate the Cr-spinel alteration in mafic and ultramafic rocks. Rock magnetism methods are cost effective, weakly destructive and do not necessitate important amounts of material. They could also be appropriate to investigate extraterrestrial spinel-bearing rock samples, allowing to track fluid/ rock interaction in primitive meteorites and thus possibly providing important clues about the origin of water on Earth (e.g., Piani et al., 2020).

\section{Conclusion}

- By combining microprobe, microscopy, Mössbauer, and magnetic data, this study reveals the potential of magnetic measurements to detect and identify the different $\mathrm{Cr}$-Fe-spinels produced by the alteration of chromiferous spinels ubiquitous in mafic and ultramafic rocks.

- Magnetic scanning microscopy confirms that coarser magnetic grain size in the North Aït Ahmane serpentinites compared to other serpentinites worldwide, as identified by hysteresis parameters (e.g., $H_{\mathrm{cr}} /$ $H_{\mathrm{c}}>4$ ), is related to $\mathrm{Cr}$-spinel alteration phases showing a strong magnetization, similar in magnitude to serpentinization related pure magnetite for external rims.

- Electron microprobe analyses reveal that these phases consist in a continuum of Fe- $\mathrm{Cr}$ spinel minerals, namely from ferritchromite to Cr-rich magnetite, characterized by $\mathrm{FeO}_{\text {Total }}$ and $\mathrm{Cr}_{2} \mathrm{O}_{3}$ contents ranging from 45.96 to 86.10 and 9.70 to $43.05 \mathrm{wt}$.\%, respectively.

- Thermomagnetic curves show that $\mathrm{Cr}$-magnetite is characterized by a Curie point of $515 \pm 11^{\circ} \mathrm{C}$ in our samples, which occurs together with the typical Curie point for pure magnetite at $580^{\circ} \mathrm{C}$ leading to a "double magnetite $T_{\mathrm{c}}$ " feature.

- We propose a new definition for the Cr-magnetite: a Cr-Fe-spinel with a Curie point of ca. $500-530^{\circ} \mathrm{C}$ defined by the structural formula $\left.\mathrm{Fe}^{2+}\left(\mathrm{Fe}_{1-n} \mathrm{Cr}_{n}\right)_{2} \mathrm{O}_{4}\right)$ with an $n$ between 0.2 and 0.1 , corresponding to $\mathrm{Cr}_{2} \mathrm{O}_{3}$ concentrations in the range of 6-13 wt.\%. For Cr-rich magnetite with $\mathrm{Cr}_{2} \mathrm{O}_{3}$ contents $<6$ wt. $\%$, the associated $T_{\mathrm{c}}$ is indistinguishable from that of pure magnetite.

- Thermomagnetic curves also allow us to characterize ferritchromite, the latter being highlighted by its destabilization into maghemite around $130^{\circ} \mathrm{C}$. This produces an increase in magnetic susceptibility from this temperature, until maghemite destabilization starting at ca. $300^{\circ} \mathrm{C}$.

- We also show that a standardized variation curve of the magnetic susceptibility upon heating allows relative quantification of the contributions of the different $\mathrm{Cr}$-spinel alteration phases to the bulk magnetic susceptibility. This allows us to establish a link between the destabilization of ferritchromite around $130^{\circ} \mathrm{C}$ into maghemite and the destabilization of this maghemite from $300^{\circ} \mathrm{C}$. Interestingly, specific covariation trends between these two magnetic species for each studied unit likely result from different alteration processes.

- In addition to petrographic observations, Mossbauer spectrometry and low temperature measurements, a clear positive correlation between the $T_{\mathrm{c}}$ measured for Cr-magnetite and the intensity of the hydrothermal signature recorded by Eu/Eu* ratios in the North Aït Ahmane serpentinites confirms that intense spinel alteration is a consequence of the hydrothermalism endured by these serpentinites despite low temperatures $\left(<300^{\circ} \mathrm{C}\right)$. This suggests that fluid-rock interactions can also strongly control spinel alteration even at low temperature, implying that significant spinel alteration is not necessarily related to high metamorphic grade.

- Cr-spinel alteration phases (ferritchromite and Cr-magnetite) are easily identifiable via the variation of magnetic susceptibility as a function of temperature and tracked by magnetic scanning microscopy. This opens the doors to magnetic investigations of the $\mathrm{Cr}$-spinel alteration state in terrestrial and extraterrestrial mafic and ultramafic rocks. 


\section{Data Availability Statement}

All data used in this manuscript (Supplementary data 1, 2, 3, 4) are available in Hodel et al. (2020) (http:// doi.org/10.5281/zenodo.3877929). Further queries and information requests should be directed to the lead author F.H. (florent.hodel.geo@gmail.com).

\section{Acknowledgments}

Authors are grateful to Fabienne De Parseval for thin sections preparation, to Philippe De Parseval and to Marco Paulo de Castro for their assistance on electron microprobes, to Thierry Aigouy for it assistance on the SEM and to Plinio Jaqueto for his help on the VSM. Authors are also grateful to the Microscopy and Microanalysis Laboratory (LMic) of the Universidade Federal de Ouro Preto, a member of the Microscopy and Microanalysis Network of Minas Gerais State/Brazil/FAPEMIG. This work has been funded by Research Grant 2016/06114-6 of the Fundação de Amparo à Pesquisa do Estado de São Paulo (FAPESP, Brazil), TelluS-SYSTER program of Institut national des sciences de l'Univers (INSU, CNRS, France), French Ministère de l'Éducation nationale, de l'Enseignement supérieur et de la Recherche (MENESR) and the PICS-CNRS (NanoPol) program. F. Hodel thank IODP France for his postdoc fellowship. The authors are also grateful to GW. ter Maat and an anonymous reviewer for their careful reading and suggestions, which significantly improved this contribution.

\section{References}

Ahmed, A. H., \& Surour, A. A. (2016). Fluid-related modifications of Cr-spinel and olivine from ophiolitic peridotites by contact metamorphism of granitic intrusions in the Ablah area, Saudi Arabia. Journal of Asian Earth Sciences, 533, 58-79. https://doi.org/10.1016/j. jseaes.2016.03.010

Arai, S. (1994). Compositional variation of olivine-chromian spinel in Mg-rich magmas as a guide to their residual spinel peridotites. Journal of Volcanology and Geothermal Research, 59, 279-293. https://doi.org/10.1016/0377-0273(94)90083-3

Araujo, J. F. D. F., Reis, A. L. A., Correa, A. A. P., Yokoyama, E., Oliveira, V. C., Mendoza, L. A. F., et al. (2019). Scanning magnetic microscope using a gradiometric configuration for characterization of rock samples. Materials, 12(24), 4154. https://doi.org/10.3390/ ma12244154

Bale, C. W., Bélisle, E., Chartrand, P., Decterov, S. A., Eriksson, G., Gheribi, A. E., et al. (2016). FactSage thermochemical software and databases, 2010-2016. Calphad, 54, 35-53. https://doi.org/10.1016/j.calphad.2016.05.002

Barlow, R. D., Jones, M. R. B., Phillips, P. J., Pointon, A. J., \& Whall, T. E. (1987). Concentration dependence of the Verwey transition in germanium- and fluorine-substituted magnetite. Journal of Applied Physics, 61(8), 3546-3548.

Barnes, S. J. (2000). Chromite in Komatiites, II. Modification during greenschist to mid-amphibolite facies metamorphism. Journal of Petrology, 41, 387-409.

Barnes, S. J., \& Roeder, P. L. (2001). The range of spinel compositions in terrestrial mafic and ultramafic rocks. Journal of Petrology, 42, 2279-2302. https://doi.org/10.1093/petrology/42.12.2279

Barra, F., Gervilla, F., Hernández, E., Reich, M., Padrón-Navarta, J. A., \& González-Jiménez, J. M. (2014). Alteration patterns of chromian spinels from La Cabaña peridotite, south-central Chile. Mineralogy and Petrology, 108, 819-836. https://doi.org/10.1007/ s00710-014-0335-5

Barrat, J. A., Zanda, B., Moynier, F., Bollinger, C., Liorzou, C., \& Bayon, G. (2012). Geochemistry of CI chondrites: Major and trace elements, and $\mathrm{Cu}$ and $\mathrm{Zn}$ isotopes. Geochimica et Cosmochimica Acta, 83, 79-92. https://doi.org/10.1016/j.gca.2011.12.011

Bonnemains, D., Carlut, J., Escartín, J., Mével, C., Andreani, M., \& Debret, B. (2016). Magnetic signatures of serpentinization at ophiolite complexes. Geochemistry, Geophysics, Geosystems, 17, 2969-2986. https://doi.org/10.1002/2016GC006321

Brabers, V. A. M., Walz, F., \& Kronmüller, H. (1998). Impurity effects upon the Verwey transition in magnetite. Physical Review B, $58,14163$.

Chhaya, U. V., Trivedi, B. S., \& Kulkarni, R. G. (1999). Magnetic properties of the mixed spinel $\mathrm{NiAl}_{2 x} \mathrm{Cr}_{x} \mathrm{Fe}_{2-3 x} \mathrm{O}_{4}$. Physica B: Condensed Matter, 262, 5-12. https://doi.org/10.1016/S0921-4526(98)00659-0

Day, R., Fuller, M., \& Schmidt, V. A. (1977). Hysteresis properties of titanomagnetites: Grain-size and compositional dependence. Physics of the Earth and Planetary Interiors, 13, 260-267. https://doi.org/10.1016/0031-9201(77)90108-X

Decterov, S. A., Jung, I. H., Jak, E., Kang, Y. B., Hayes, P., \& Pelton, A. D. (2004). Thermodynamic modelling of the Al2O3-CaO-CoO$\mathrm{CrO}-\mathrm{Cr} 2 \mathrm{O} 3-\mathrm{FeO}-\mathrm{Fe} 2 \mathrm{O} 3-\mathrm{MgO}-\mathrm{MnO}-\mathrm{NiO}-\mathrm{SiO} 2-\mathrm{S}$ system and applications in ferrous process metallurgy. Vii International Conference on Molten Slags Fluxes and Salts. Cape Town, South Africa, pp. 839-850.

Dick, H. J. B., \& Bullen, T. (1984). Chromian spinel as a petrogenetic indicator in abyssal and alpine-type peridotites and spatially associated lavas. Contributions to Mineralogy and Petrology, 86, 54-76. https://doi.org/10.1007/BF00373711

Domenichini, B., Amilain-Basset, K., \& Bourgeois, S. (2002). Dynamic segregation during ferrite oxidation revealed by XPS. Surface and Interface Analysis, 34, 527-530. https://doi.org/10.1002/sia.1353

Doriguetto, A. C., Fernandes, N. G., Persiano, A. I. C., Nunes Filho, E., Grenèche, J. M., \& Fabris, J. D. (2003). Characterization of a natural magnetite. Physics and Chemistry of Minerals, 30, 249-255. https://doi.org/10.1007/s00269-003-0310-x

Droop, G. T. R. (1987). A general equation for estimating $\mathrm{Fe}^{3+}$ concentrations in ferromagnesian silicates and oxides from microprobe analyses, using stoichiometric criteria. Mineralogical Magazine, 51, 431-435.

Dunlop, D. J. (2002a). Theory and application of the Day plot $\left(\mathrm{M}_{\mathrm{rs}} / \mathrm{M}_{\mathrm{s}}\right.$ versus $\left.\mathrm{H}_{\mathrm{cr}} / \mathrm{H}_{\mathrm{c}}\right)$ 2. Application to data for rocks, sediments, and soils. Journal of Geophysical Research, 107, 2057. https://doi.org/10.1029/2001JB000487

Dunlop, D. J. (2002b). Theory and application of the Day plot $\left(\mathrm{M}_{\mathrm{rs}} / \mathrm{M}_{\mathrm{s}}\right.$ versus $\left.\mathrm{H}_{\mathrm{cr}} / \mathrm{H}_{\mathrm{c}}\right) 1$. Theoretical curves and tests using titanomagnetite data. Journal of Geophysical Research, 107, 2057. https://doi.org/10.1029/2001JB000486

Dunlop, D. J., \& Ozdemir, O. (1997). Rock magnetism, fundamentals and frontiers. Cambridge, UK: Cambridge University Press.

Egli, R. (2003). Analysis of the field dependence of remanent magnetization curves. Journal of Geophysical Research, 108(B2), 2081. https://doi.org/10.1029/2002jb002023

Egli, R. (2004). Characterization of individual rock magnetic components by analysis of remanence curves, 1 . Unmixing natural sediments. Studia Geophysica et Geodaetica, 48, 391-446. https://doi.org/10.1023/B:SGEG.0000020839.45304.6d

El Dien, G. H., Arai, S., Doucet, L. S., Li, Z. X., Kil, Y., Fougerouse, D., et al. (2019). Cr-spinel records metasomatism not petrogenesis of mantle rocks. Nature Communications, 10, 1-12. https://doi.org/10.1038/s41467-019-13117-1

Evans, B. W. (2004). The serpentinite multisystem revisited: Chrysotile is metastable. International Geology Review, 46, 479-506. https:// doi.org/10.2747/0020-6814.46.6.479

Fujii, M., Okino, K., Sato, H., Nakamura, K., Sato, T., \& Yamazaki, T. (2016). Variation in magnetic properties of serpentinized peridotites exposed on the Yokoniwa Rise, Central Indian Ridge: Insights into the role of magnetite in serpentinization. Geochemistry, Geophysics, Geosystems, 17, 5024-5035. https://doi.org/10.1002/2016GC006511

Gattacceca, J., Rochette, P., Lagroix, F., Mathé, P.-E., \& Zanda, B. (2011). Low temperature magnetic transition of chromite in ordinary chondrites. Geophysical Research Letters, 38, L10203. https://doi.org/10.1029/2011GL047173

Gehring, A. U., Fischer, H., Louvel, M., Kunze, K., \& Weidler, P. G. (2009). High temperature stability of natural maghemite: A magnetic and spectroscopic study. Geophysical Journal International, 179(3), 1361-1371. https://doi.org/10.1111/j.1365-246X.2009.04348.x

González-Jiménez, J. M., Kerestedjian, T., Fernández, J. A. P., \& Linares, F. G. (2009). Metamorphism on chromite ores from the Dobromirtsi Ultramafic Massif, Rhodope Mountains (SE Bulgaria). Geológica Acta, 7, 413-429. 
Harrison, R. J., \& Feinberg, J. M. (2008). FORCinel: An improved algorithm for calculating first-order reversal curve distributions using locally weighted regression smoothing. Geochemistry, Geophysics, Geosystems, 9, Q05016. https://doi.org/10.1029/2008GC001987

Heslop, D., McIntosh, G., \& Dekkers, M. J. (2004). Using time- and temperature-dependent Preisach models to investigate the limitations of modelling isothermal remanent magnetization acquisition curves with cumulative log Gaussian functions. Geophysical Journal International, 157, 55-63. https://doi.org/10.1111/j.1365-246X.2004.02155.X

Hodel, F. (2017). Neoproterozoic serpentinites: A window on the oceanic lithosphere associated with the Rodinia break-up (Doctoral dissertation). Toulouse, France: Université Toulouse III Paul Sabatier.

Hodel, F., Macouin, M., Triantafyllou, A., Carlut, J., Berger, J., Rousse, S., et al. (2017). Unusual massive magnetite veins and highly altered Cr-spinels as relics of a Cl-rich acidic hydrothermal event in Neoproterozoic serpentinites (Bou Azzer ophiolite, Anti-Atlas, Morocco). Precambrian Research, 300, 151-167. https://doi.org/10.1016/j.precamres.2017.08.005

Hodel, F., Macouin, M., Trindade, R. I. F., Triantafyllou, A., Ganne, J., Chavagnac, V., et al. (2018). Fossil black smoker yields oxygen isotopic composition of Neoproterozoic seawater. Nature Communications, 9, 1453. https://doi.org/10.1038/s41467-018-03890-w

Hodel, F., Triantafyllou, A., Berger, J., Macouin, M., Baele, J. M., Mattielli, N., et al. (2020). The Moroccan Anti-Atlas ophiolites: Timing and melting processes in an intra-oceanic arc-back-arc environment. Gondwana Research, 86, 182-202. https://doi.org/10.1016/j. gr.2020.05.014

Hodel, F., Trindade, R. I. F., Macouin, M., Meira, V. T., Dantas, E. L., Paixão, M. A. P., et al. (2019). A Neoproterozoic hyper-extended margin associated with Rodinia's demise and Gondwana's build-up: The Araguaia Belt, central Brazil. Gondwana Research, 66, 43-62 https://doi.org/10.1016/J.GR.2018.08.010

Holser, W. T., \& Schneer, C. J. (1961). Hydrothermal magnetite. The Geological Society of America Bulletin, 72, 369. https://doi.org/10.113 0/0016-7606(1961)72[369:HM]2.0.CO;2

Honig, J. M. (1995). Analysis of the Verwey transition in magnetite. Journal of Alloys and Compounds, 229(1), 24-39.

Horen, H., Soubrand, M., Kierczak, J., Joussein, E., \& Néel, C. (2014). Magnetic characterization of ferrichromite in soils developed on serpentinites under temperate climate. Geoderma, 235, 83-89. https://doi.org/10.1016/j.geoderma.2014.06.026

Ishii, T., Robinson, P. T., Maekawa, H., \& Fiske, R. (1992). Petrological studies of peridotites from diapiric serpentinite seamounts in the Izu-Ogasawara-Mariana Forearc, Leg 125. Proceedings of the ocean drilling program, 125 scientific results, Ocean Drilling Program, 445-486. https://doi.org/10.2973/odp.proc.sr.125.129.1992

Kakol, Z. (1990). Magnetic and transport properties of magnetite in the vicinity of the Verwey transition. Journal of Solid State Chemistry, $88(1), 104-114$

Kalczynski, M. J., \& Gates, A. E. (2014). Hydrothermal alteration, mass transfer and magnetite mineralization in dextral shear zones, western Hudson Highlands, New York, United States. Ore Geology Reviews, 61, 226-247. https://doi.org/10.1016/j.oregeorev.2014.02.007

Kruiver, P. P., Dekkers, M. J., \& Heslop, D. (2001). Quantification of magnetic coercivity components by the analysis of acquisition curves of isothermal remanent magnetisation. Earth and Planetary Science Letters, 189, 269-276.

Kądziałko-Hofmokl, M., Delura, K., Bylina, P., Jeleńska, M., \& Kruczyk, J. (2008). Mineralogy and magnetism of Fe-Cr spinel series minerals from podiform chromitites and dunites from Tąpadła (Sudetic ophiolite, SW Poland) and their relationship to paleomagnetic results of the dunites. Geophysical Journal International, 175, 885-900. https://doi.org/10.1111/j.1365-246X.2008.03933.x

Kądziałko-Hofmokl, M., Jeleńska, M., Delura, K., \& Bylina, P. (2010). Magnetic mineralogy and paleomagnetism of serpentinized ultramafic rocks from the Braszowice-Brzeźnica fragment of Sudetic paleozoic ophiolite. Acta Geophysica, 58, 269-299. https://doi. org/10.2478/s11600-009-0054-1

Lenaz, D., Skogby, H., Princivalle, F., \& lenius, H. U. (2004). Structural changes and valence states in the $\mathrm{MgCr}_{2} \mathrm{O}_{4}-\mathrm{FeCr}_{2} \mathrm{O}_{4}$ solid solution series. Physics and Chemistry of Minerals, 31, 633-642. https://doi.org/10.1007/s00269-004-0420-0

Maffione, M., Morris, A., Plümper, O., \& van Hinsbergen, D. J. J. (2014). Magnetic properties of variably serpentinized peridotites and their implication for the evolution of oceanic core complexes. Geochemistry, Geophysics, Geosystems, 15, 923-944. https://doi. org/10.1002/2013GC004993

Marques, A. F. A., Barriga, F. J. A. S., \& Scott, S. D. (2007). Sulfide mineralization in an ultramafic-rock hosted seafloor hydrothermal system: From serpentinization to the formation of $\mathrm{Cu}-\mathrm{Zn}-(\mathrm{Co})$-rich massive sulfides. Marine Geology, 245, 20-39. https://doi org/10.1016/j.margeo.2007.05.007

Maxbauer, D. P., Feinberg, J. M., \& Fox, D. L. (2016). MAX UnMix: A web application for unmixing magnetic coercivity distributions. Computers \& Geosciences, 95, 140-145. https://doi.org/10.1016/j.cageo.2016.07.009

Mellini, M., Rumori, C., \& Viti, C. (2005). Hydrothermally reset magmatic spinels in retrograde serpentinites: Formation of "ferritchromit" rims and chlorite aureoles. Contributions to Mineralogy and Petrology, 149, 266-275. https://doi.org/10.1007/s00410-005-0654-y

Mével, C. (2003). Serpentinization of abyssal peridotites at mid-ocean ridges. Comptes Rendus Geoscience, 335, 825-852. https://doi. org/10.1016/j.crte.2003.08.006

Oufi, O., Cannat, M., \& Horen, H. (2002). Magnetic properties of variably serpentinized abyssal peridotites. Journal of Geophysical Research, 107, 2095. https://doi.org/10.1029/2001JB000549

Özdemir, O., Dunlop, D. J., \& Moskowitz, B. M. (1993). The effect of oxidation on the Verwey transition in magnetite. Geophysical Research Letters, 20(16), 1671-1674.

O'Hanley, D. S. (1996). Serpentinite: Record of tectonic and petrologic history (p. 277). Oxford, UK: Oxford University Press.

O'Hanley, D. S., \& Dyar, M. D. (1993). The composition of lizardite 1T and the formation of magnetite in serpentinites I American Mineralogist I GeoScienceWorld. American Mineralogist, 78, 391-404.

Pearce, J. A., Barker, P. F., Edwards, S. J., Parkinson, I. J., \& Leat, P. T. (2000). Geochemistry and tectonic significance of peridotites from the South Sandwich arc-basin system, South Atlantic. Contributions to Mineralogy and Petrology, 139, 36-53. https://doi.org/10.1007/ s004100050572

Pereira, J. M. B., Pacheco, C. J., Arenas, M. P., Araujo, J. F. D. F., Pereira, G. R., \& Bruno, A. C. (2017). Novel scanning dc-susceptometer for characterization of heat-resistant steels with different states of aging. Journal of Magnetism and Magnetic Materials, 442, 311-318. https://doi.org/10.1016/j.jmmm.2017.07.004

Petersen, N., \& Bleil, U. (1982). Curie temperature. In G. Angenheister (Ed.), Landolt-Börnstein: Numerical data and functional rela-tionships in science and technology (Vol. 1B). Berlin, Germany: SpringerMaterials: The Landolt-Börnstein database. https://doi org/10.1007/10201909_76

Petrovský, E., \& Kapička, A. (2006). On determination of the Curie point from thermomagnetic curves. Journal of Geophysical Research, 111, B12S27. https://doi.org/10.1029/2006JB004507

Piani, L., Marrocchi, Y., Rigaudier, T., Vacher, L. G., Thomassin, D., \& Marty, B. (2020). Earth's water may have been inherited from mate- 
Purtov, V. K., Kholodnov, V. V., Anfilogov, V. N., \& Nechkin, G. S. (1989). The role of chlorine in the formation of magnetite skarns. International Geology Review, 31, 63-71.

Robbins, M., Wertheim, G. K., Sherwood, R. C., \& Buchanan, D. N. E. (1971). Magnetic properties and site distributions in the system Fe$\mathrm{Cr}_{2} \mathrm{O}_{4}-\mathrm{Fe}_{3} \mathrm{O}_{4}\left(\mathrm{Fe}^{2}+\mathrm{Cr}_{2-x} \mathrm{Fe}_{x}{ }^{3+} \mathrm{O}_{4}\right)$. Journal of Physics and Chemistry of Solids, 32, 717-729. https://doi.org/10.1016/S0022-3697(71)80412-2

Roberts, A. P., Pike, C. R., \& Verosub, K. L. (2000). First-order reversal curve diagrams: A new tool for characterizing the magnetic properties of natural samples. Journal of Geophysical Research, 105, 28461-28475. https://doi.org/10.1029/2000JB900326

Sandu, V., Cimpoiasu, E., Kuncser, A., \& Nicolescu, M. S. (2017). Magnetic properties of glass-ceramics obtained by crystallization of ironrich borosilicate glasses. Journal of Advanced Ceramics, 6, 251-261. https://doi.org/10.1007/s40145-017-0236-2

Saumur, B. M., \& Hattori, K. (2013). Zoned Cr-spinel and ferritchromite alteration in forearc mantle serpentinites of the Rio San Juan Complex, Dominican Republic. Mineralogical Magazine, 77(1), 117-136.

Schwartz, S., Lafay, R., Debret, B., Nicollet, C., Lanari, P., \& Auzende, A. L. (2013). Pressure-temperature estimates of the lizardite/antigorite transition in high pressure serpentinites. Lithos, 178, 197-210. https://doi.org/10.1016/j.lithos.2012.11.023

Taylor, J. R., \& Dinsdale, A. T. (1993). A thermodynamic assessment of the Cr-Fe-O system. Zeitschrift für Metallkunde, 84, $335-345$.

Ziemniak, S. E., \& Castelli, R. A. (2003). Immiscibility in the $\mathrm{Fe}_{3} \mathrm{O}_{4}-\mathrm{FeCr}_{2} \mathrm{O}_{4}$ spinel binary. Journal of Physics and Chemistry of Solids, 64, 2081-2091. https://doi.org/10.1016/S0022-3697(03)00237-3 